\title{
Original paper \\ Radiogenic heat production of Variscan granites from the Western Bohemian Massif, Germany
}

\author{
Lars SCHARFENBERG ${ }^{1,2^{*}}$, Anette REGELOUS ${ }^{1}$, Helga DE WALL \\ ${ }^{1}$ GeoZentrum Nordbayern, Friedrich-Alexander-Universität Erlangen-Nürnberg, Schlossgarten 5, D-91054 Erlangen, Germany \\ 2 Present address: Department für Geodynamik und Sedimentologie, Department für Lithosphärenforschung, Universität Wien, \\ Althanstraße 14, A-1190Vienna, Austria; lars.scharfenberg@univie.ac.at \\ * Corresponding author
}

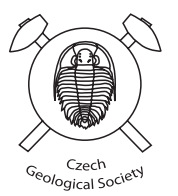

\begin{abstract}
Much of the Mid-European basement has been consolidated during the Variscan Orogeny and includes large volumes of granitic intrusions. Gamma radiation spectroscopic measurements in three study areas along the western margin of the Bohemian Massif give a record of radiogenic element concentrations in the Variscan granites. Most intrusions of the Fichtelgebirge (except for the Tin Granite) and intrusive complexes in the Bavarian Forest show $\mathrm{Th} / \mathrm{U}$ ratios exceeding unity, most likely related to abundance of monazite. In contrast, some of the Oberpfalz granites located near the Saxothuringian-Moldanubian boundary (Flossenbürg, Steinwald and Friedenfels types) are characterized by higher uranium concentrations and thus $\mathrm{Th} / \mathrm{U}<1$. The low $\mathrm{Th} / \mathrm{U}$ ratios here are in agreement with a possible $\mathrm{U}$ mobilisation along the Saxothuringian-Moldanubian contact zone observed in previous studies. Heat production rates of granites in the three study areas vary between 3.9 and $8.9 \mu \mathrm{W} / \mathrm{m}^{3}$, with a mean of $4.9 \mu \mathrm{W} / \mathrm{m}^{3}$. This classifies the intrusions as moderate- to high-heat-producing granites. Considering the huge volume of granitic bodies in the Variscan crust of the Bohemian Massif, the contribution of in situ radiogenic heat production had to have a major impact and should be considered in further thermal modeling.
\end{abstract}

Keywords: Variscan granites, gamma spectrometry, heat production, Uranium, Thorium, Bohemian Massif Received: 28 February 2019; accepted: 10 December 2019; handling editor: P. Hasalová

The online version of this article (doi: 10.3190/jgeosci.293) contains supplementary electronic material

\section{Introduction}

From global geochemical models, the average heat production of the continental crust is estimated to be below $1 \mu \mathrm{W} / \mathrm{m}^{3}$ (Jaupart et al. 2016). Heat production rates of granites with a mean of $3.54 \mu \mathrm{W} / \mathrm{m}^{3}$ (Hasterok and Webb 2017) are well above this value and granites will represent distinct anomalies in the total crustal heat budget. These anomalies vary in magnitude depending on the age and composition of the granites that cause them (Vilà et al. 2010; Mareschal and Jaupart 2013; Jaupart et al. 2016). Heat is generated by the decay of radiogenic isotopes (mainly ${ }^{40} \mathrm{~K},{ }^{232} \mathrm{Th},{ }^{238} \mathrm{U},{ }^{235} \mathrm{U}$ ), the latter two elements mostly concentrated within accessory minerals such as zircon and monazite. These minerals are generally enriched in felsic magmas and granitic intrusions and (are considered as) main cause of accumulation of heat-producing elements in the upper crust (e.g., Bea 1996, 2012). Especially granitic terrains are therefore in the focus of worldwide geothermal prospection (e.g., McLaren et al. 2003; Beardsmore 2004; Ledésert and Hébert 2012; Siégel et al. 2012; Chandrasekharam et al. 2014; Adams et al. 2015; Lüschen et al. 2015).

As radiogenic heat contributes significantly to the thermal budget of the continental crust it has a major influence on the surface heat flow. Hasterok and Chapman (2011) estimated that $26 \%$ of the surface heat flow is generated by the upper continental crust. The new database GRANITE2017 has been set up to compile available data on worldwide granitic terrains of all ages (Artemieva et al. 2017). Based on statistical analysis, first conclusions have been made on variation of bulk heat production of granites through geological time. These results show a peak in the Middle Proterozoic times and a gradual decrease towards younger (Cenozoic) intrusions. In contrast, Gard et al. (2019) found the heat production relatively constant from $2.8 \mathrm{Ga}$ to present. However, as there are strong variations in radioelement concentrations within individual granitic suites, more data are necessary to substantiate the database on radiogenic-heat production (RHP) of granites.

Much of the basement in Mid-Europe has been consolidated during the Variscan Orogeny (Fig. 1a). Large granitic terrains within the Variscan Belt are exposed e.g. in Central Iberia (Bea et al. 2003), the Corsica-Sardinian Batholith (Casini et al. 2015) and the Cornubian granites (Floyd 1972; Edwards 1984). Specific examples for heat flow anomalies include the Cornubian geothermal province (Beamish and Busby 2016), the Iberian Peninsula (Fernández et al. 1998) or the Erzgebirge as part of the Bohemian Massif (Förster and Förster 2000). 


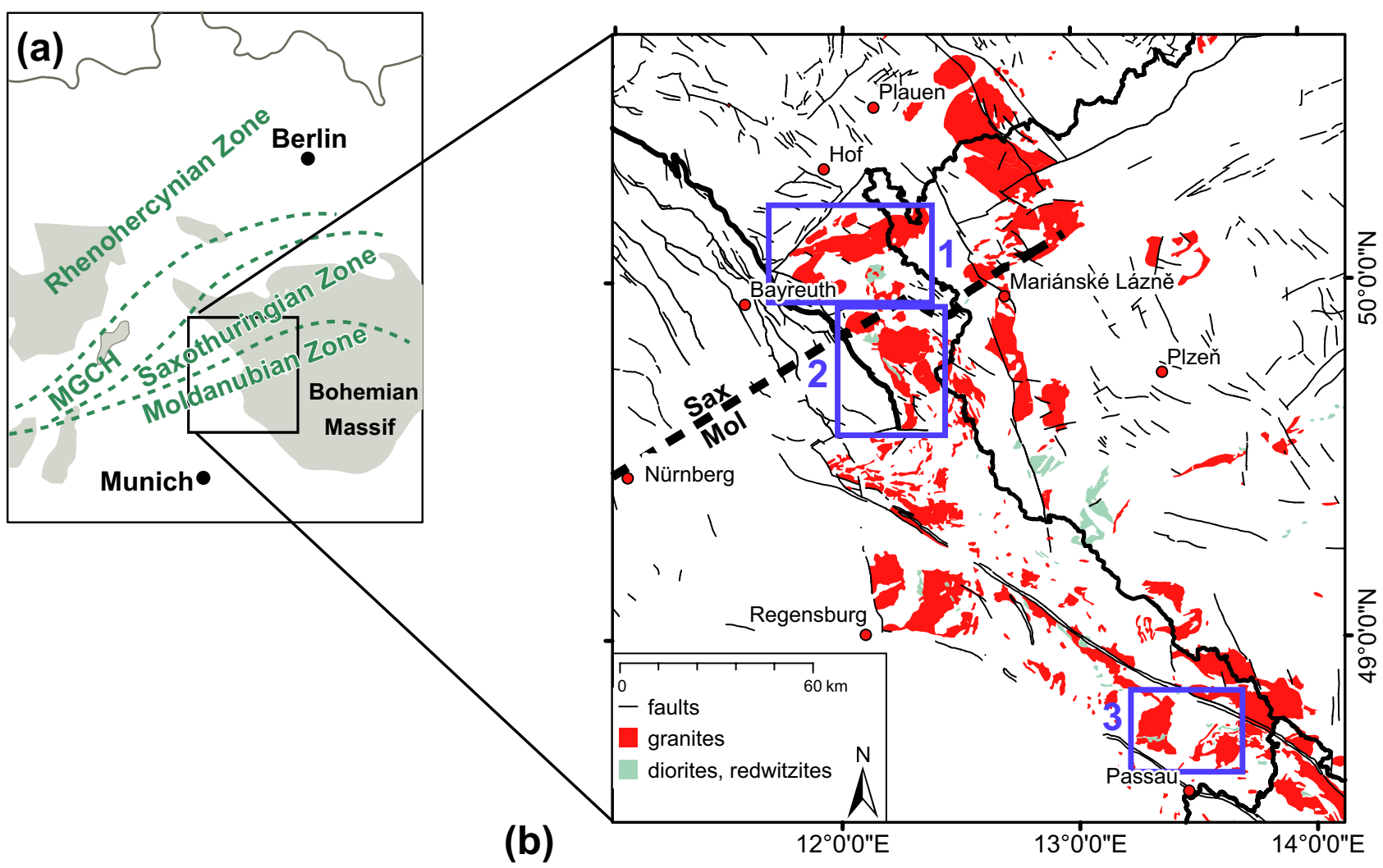

Fig. 1 Location of study area (a) and granite distribution (b) along the western margin of the Bohemian Massif. Granite areas examined in this study: 1 - Fichtelgebirge, 2 - Oberpfalz, 3 - Bavarian Forest. MGCH - Mid German Crystalline High, SAX - Saxothuringian Zone, MOL - Moldanubian Zone.

The Bohemian Massif represents the largest exposure of Variscan crust in Europe and it was intruded by numerous granitic bodies related to its long Variscan history (Fig. 1b; for review see Žák et al. 2014). It was characterised by episodic melt generation with several magma pulses from Visean to Permian times (Schaltegger 1997). The orogenic processes triggered large-scale anatexis of the Variscan orogenic crust, exposed e.g. in the Bavarian Forest (Kalt et al. 1999; Siebel et al. 2012). Wrench tectonics at the late stage of crustal convergence has also initiated melt propagation along fracture zones (Trzebski et al. 1997; Žák et al. 2014). In the Saxothuringian Zone, late- to post-Variscan uplift and exhumation was accompanied by intense felsic I-, S- to A-type magmatism (Förster and Romer 2010; Breiter 2012). Granites reflecting this complex history exposed along the western margin of the Bohemian Massif (e.g. Siebel et al. 2003; Finger et al. 2009; Siebel and Chen 2010; Fig. 1b) are target of this study.

In addition to their significance for present-day heat flow anomalies in the Mid-European crust, the contribution of radioactive heating is also discussed as trigger mechanism for orogenic processes during the Variscan convergence (Gerdes et al. 2000; Lexa et al. 2011). However, inferences are based on thermal models that require reliable input data. Heat production data can be calculated from the radioelement concentrations in rock units (Rybach 1988), in turn obtained by geochemical analyses or by gamma radiation spectroscopic measurements. The latter method is a widely used surveying technique both in rocks and soils (e.g. Frattini et al. 2006; Šimíček et al. 2012; McCay et al. 2014; Puccini et al. 2014; Scharfenberg et al. 2016; Harley et al. 2017). In granitic terrains, an advantage of gamma-ray spectroscopy over chemical analysis is the easier mapping and therefore better regional coverage (Gnojek et al. 2018; Scharfenberg et al. 2019).

In this paper we have compiled heat production data from three study areas along the western Margin of the Bohemian Massif (Fig. 1b). The granites studied here are representative of Variscan intrusions with different petrogenetic signatures (Hecht et al. 1997; Siebel et al. 1997). They cover the Saxothuringian Zone (Fichtelgebirge, area 1), the Moldanubian Zone (Bavarian Forest, area 3 ) and the granite exposures in the transition zone in between these two Variscan units (Oberpfalz, area 2). We show here differences in heat production rates, $\mathrm{Th} / \mathrm{U}$ ratios and radioelement concentrations between the studied areas, and attribute these to the regional changes in the petrogenetic evolution producing extensive I-type 
magmatism in the Bavarian Forest and I- to S- type magmatism in the Saxothuringian Zone.

\section{Variscan granites along the western margin of the Bohemian Massif}

During the Variscan Orogeny, thickening of the crust and northward directed propagation resulted in Carboniferous thrusting and stacking and associated metamorphism at 315-325 Ma (O'Brien et al. 1997). Late to post-orogenic granites (I-, S- and A-type) intruded this setting over a period of about $60 \mathrm{Myr}$ (326 to $286 \mathrm{Ma}$; Siebel et al. 1997, 2003; Siebel and Chen 2010; Breiter 2012). Within all studied areas (Fig. 1b), the granite intrusions were related to a sequence of magmatic events. The Fichtelgebirge and Oberpfalz granites (study areas 1 and 2, see Fig. 1) are peraluminous to metaluminous S- to I-type granites that formed through anatexis of metasedimentary and metaigneous rocks in the middle or lower crust. The intrusions are commonly divided into an older (OIC) and a younger (YIC) granitic suites (Richter and Stettner 1979; Hecht et al. 1997). Precursors of the granites, the redwitzites (diorites), are predominately metaluminous and interpreted as products of crystallization of a mantle-derived mafic magma (Kováŕíková et al. 2007). For the OIC, a contribution of melt from deeper sources is considered and these granites range from S-type to transitional I-/S-type (Siebel et al. 1997, 2003 and references therein). Granites in the Bavarian Forest (study area 3) are classified as monzogranites varying from weakly peraluminous biotite granites to moderately or strongly peraluminous biotite \pm muscovite granites (Siebel and Chen 2010 and references therein). Table 1 gives an overview of the petrography, ages and textural facies of the studied granites.

\subsection{Area 1: Fichtelgebirge}

Intrusions of dioritic to granodioritic composition (redwitzites, local name for diorites) occurred at c. 323 Ma (Siebel et al. 2003), representing the initial phase of late-orogenic magmatism in the Fichtelgebirge (Fig. 1b). The geochemical and isotopic signatures show that these rocks were derived by mixing between mafic and felsic magmas (Siebel and Chen 2010). The first pulse of granitic magma, the OIC, gave crystallization ages of 326-324 Ma (Hecht et al. 1997; Siebel et al. 2003), thus overlapping with the redwitzites. This first pulse of granitic magma had I-type affinity and the OIC-Redwitzite Suite was interpreted as a product of partial melting of crustal rocks triggered by, and mixed with, mantle-derived melts (Siebel et al. 1997,
2003). In the Fichtelgebirge, the emplacement of the younger suite of S-type granites (YIC) is confined to an age range of 298 to $286 \mathrm{Ma}$ (see Tab. 1). Besides the biotite-muscovite granites, a further granite type occurs (G2K and G3K, Kösseine granites - Förster 2000). These granites are inhomogeneous, less evolved monzogranites, rich in peraluminous minerals (garnet, cordierite, sillimanite) due to uncomplete restite separation. Thomas and Klemm (1994) have constrained the intrusion depth of the highly fractionated G4 Tin Granite by analysis of melt inclusions. The shallow intrusion $(<5 \mathrm{~km})$ occurred into already uplifted OIC and YIC granites underlining the rapid late Variscan exhumation. A pre-Permian uplift of at least $7 \mathrm{~km}$ has also been inferred from microstructural analyses on Saxothuringian basement rocks (de Wall et al. 2019). Granites of the Fichtelgebirge area have been subject of a previous study on natural gamma radiation and heat production (Scharfenberg et al. 2016). Results of this study are included here for comparison.

\subsection{Area 2: Oberpfalz}

The weakly peraluminous OIC biotite granites in the Oberpfalz area (Zainhammer-Leuchtenberg Granite, 324 to $321 \mathrm{Ma}$, Siebel et al. 2003) form a NW-SE trending belt. Redwitzites as precursors of the granites are locally aligned. The Older Intrusive Complex (OIC) granite emplacement was modelled as a steep sheet intrusion into a transpressional wrench fault (Trzebski et al. 1997). The Younger Intrusive Complex (YIC) biotite-muscovite to muscovite granites (Falkenberg, Steinwald, Friedenfels and Flossenbürg types), cover an age range of 315 to $310 \mathrm{Ma}$ (Tab. 1). These plutons have been intruded along fault intersections within the Moldanubian-Saxothuringian suture zone. Largest intrusion of this younger suite is the Falkenberg Granite, whose depth of intrusion was constrained at 9 to $12 \mathrm{~km}$ (Zulauf et al. 1997).

\subsection{Area 3: Bavarian Forest}

The Bavarian Forest is a part of the Moldanubian Zone, high-grade core of the internal part of the Variscan Orogen (Schulmann et al. 2009). Diorites to granodiorites have been emplaced along deep reaching lineaments in the continental crust, e.g. the palites (granodiorites with mafic enclaves) along the Bavarian Shear Zone (332 Ma, Siebel et al. 2005). In contrast, diorites of the Fürstenstein Massif (334-332 Ma, Chen and Siebel 2004) are considered to be emplaced in tension gashes as an early magmatic phase (Dietl et al. 2006). Regional high-temperature metamorphism 
Tab. 1 Petrography, age and textural facies of the studied granitoids

\begin{tabular}{|c|c|c|c|}
\hline Rock type & & Petrography & Age \\
\hline \multicolumn{4}{|c|}{ Area 1: Fichtelgebirge } \\
\hline $\begin{array}{l}\text { Redwitzites (diorites) } \\
\text { I-type diorites }\end{array}$ & & Fine- to medium-grained granodiorite to gabbro & $323 \mathrm{Ma}^{2}$ \\
\hline \multirow{5}{*}{$\begin{array}{l}\text { Older Intrusive } \\
\text { Complex (OIC) } \\
\text { I-type to S-type } \\
\text { granites }\end{array}$} & G1, porphyritic granite & Porphyritic, medium- to coarse-grained biotite granite & $324.2 \pm 4.2 \mathrm{Ma}^{2}$ \\
\hline & G1R, "Reut Granite" & Fine- to medium-grained, slightly porphyritic biotite granite & $326 \pm 2 \mathrm{Ma}^{1}$ \\
\hline & G1HS, "Holzmühl Granite" & $\begin{array}{l}\text { Medium- to coarse-grained two-mica granite, } \\
\text { only local occurrence }\end{array}$ & \\
\hline & G1S, "Selb Granite" & $\begin{array}{l}\text { only local occurrence } \\
\text { Fine- to medium-grained two-mica granite }\end{array}$ & $326 \pm 2 \mathrm{Ma}^{1}$ \\
\hline & G1Sm, muscovite granite & $\begin{array}{l}\text { Fine- to medium-grained muscovite granite, occurs in the Czech } \\
\text { part of the Fichtelgebirge/Smrčiny Pluton }\end{array}$ & \\
\hline \multirow{6}{*}{$\begin{array}{l}\text { Younger Intrusive } \\
\text { Complex (YIC) } \\
\text { S-type granites }\end{array}$} & G2, "Rand Granite" & Porphyritic, fine- to medium-grained two-mica granite & $298.5 \pm 3.9 \mathrm{Ma}^{1}$ \\
\hline & G3, "Kern Granite” & Medium- to coarse-grained two-mica granite & $291.2 \pm 6.4 \mathrm{Ma}^{1}$ \\
\hline & G4, "Tin Granite" & Medium- to coarse-grained two-mica granite & $298.2 \pm 1.6^{1}$ \\
\hline & G2*, "Rand Granite" & Weakly porphyritic, fine- to medium-grained two-mica granite & $289 \pm 2 \mathrm{Ma}^{1}$ \\
\hline & G2K, "Kösseine Granite" & Medium-grained, weakly porphyritic biotite granite & $287 \pm 3 \mathrm{Ma}^{1}$ \\
\hline & G3K, "Kösseine Kern Granite" & Coarse-grained, garnet- and cordierite-bearing biotite granite & $286 \pm 26 \mathrm{Ma}^{1}$ \\
\hline \multicolumn{4}{|c|}{ Area 2: Oberpfalz } \\
\hline $\begin{array}{l}\text { Redwitzites } \\
\text { I-type diorites }\end{array}$ & & Fine- to medium-grained granodiorite to gabbro) & $323 \mathrm{Ma}^{2}$ \\
\hline \multirow{2}{*}{$\begin{array}{l}\text { Older Intrusive } \\
\text { Complex (OIC) } \\
\text { I-type to S-type } \\
\text { granites }\end{array}$} & Le, Leuchtenberg & $\begin{array}{l}\text { Medium- to coarse-grained porphyritic biotite monzogranite-gra- } \\
\text { nodiorite }^{2)} \text {; in the southern part fine- to medium-grained muscovite } \\
\text { granite }^{1)}\end{array}$ & $324-321 \mathrm{Ma}^{2}$ \\
\hline & Za, Zainhammer & Fine-medium-grained, partly porphyritic monzogranite ${ }^{2)}$ & \\
\hline \multirow{5}{*}{$\begin{array}{l}\text { Younger Intrusive } \\
\text { Complex (YIC) } \\
\text { S-type granites }\end{array}$} & Fa, Falkenberg & Porphyritic two-mica granite) & \multirow{3}{*}{$\sim 315 \mathrm{Ma}^{2}$} \\
\hline & Li, Liebenstein & Coarse-grained, \pm porphyritic muscovite monzogranite ${ }^{2)}$ & \\
\hline & Fr, Friedenfels & Medium-grained \pm porphyritic muscovite leucogranite ${ }^{2)}$ & \\
\hline & St, Steinwald & Medium-grained \pm porphyritic muscovite leucogranite ${ }^{2)}$ & \multirow[t]{2}{*}{$312-310 \mathrm{Ma}^{2}$} \\
\hline & F1, Flossenbürg & Medium grained \pm porphyritic muscovite leucogranite ${ }^{2)}$ & \\
\hline \multirow{4}{*}{$\begin{array}{l}\text { Hauzenberg Pluton } \\
\text { S-type granites }\end{array}$} & \multicolumn{2}{|r|}{ Area 3: Bavarian Forest } & \\
\hline & Hauz1 Granite & Fine- to medium-grained two-mica granite & $319 \pm 3 \mathrm{Ma}^{3}$ \\
\hline & Hauz2 Granite & Medium- to coarse-grained, two-mica granite & $329 \pm 7 \mathrm{Ma}^{3}$ \\
\hline & HauzGd, "Granodiorite" & Fine-grained, biotite-bearing granitoid & $319 \pm 4 \mathrm{Ma}^{3}$ \\
\hline \multirow{5}{*}{$\begin{array}{l}\text { Fürstenstein Pluton } \\
\text { I-type diorites, I- to } \\
\text { S-type granites }\end{array}$} & Dt, "Diorites" & Fine- to medium-grained, heterogeneous diorites to granodiorites & $334-332 \mathrm{Ma}^{4}$ \\
\hline & Bt Ms Gr/Two-mica Granite & Fine- to medium-grained biotite-muscovite granite & \multirow{2}{*}{$324-321 \mathrm{Ma}^{4}$} \\
\hline & Ti, Tittling Granite & Medium- to coarse-grained granite to granodiorite & \\
\hline & Eb, Eberhardsreuth Granite & Medium-grained biotite granite & $318-312 \mathrm{Ma}^{4}$ \\
\hline & Sa, Saldenburg Granite & Porphyritic, medium- to coarse-grained biotite granite & $316-312 \mathrm{Ma}^{4}$ \\
\hline
\end{tabular}

associated with migmatization of Moldanubian rock in the Bavarian Forest is constrained between 326 and 322 Ma (Kalt et al. 2000; Siebel et al. 2012). This event was accompanied by intrusion of large batches of granites, e.g. in the Fürstenstein and Hauzenberg plutons, both formed by different intrusive pulses between 330 and $320 \mathrm{Ma}$ (Tab. 1). These intrusions are studied here in detail as representatives of the Moldanubian granitic magmatism. In contrast to the areas 1 and 2, the Bavarian Forest (Fig. 1b) exposes a deeply eroded middle- to lower continental crust (Kalt et al. 2000). Depth of the granite intrusion has been estimated at 16 to $18 \mathrm{~km}$ for the Hauzenberg Pluton (phengite barometry, Klein et al. 2008).

\section{Methods}

\subsection{Measurements of natural gamma radiation}

In situ gamma-ray spectra were acquired on outcrops, covering the various granite types and some of the typical host rocks. During field campaigns in 2014 and 2018 we collected a total of 829 assays on in situ exposures of granitoids (granites, granodiorites, diorites) in the three key areas with a portable gammaray spectrometer (all obtained data are summarized in Electronic Supplementary Material, ESM 1). In addition, some granitoids belonging to host rocks of 
the intrusions have also been evaluated. This indirect detection of potassium, uranium and thorium by means of gamma-rays emitted by their decay products has been used as database for calculation of the radiogenic heat production (RHP) of granites in western sector of the Bohemian Massif.

Gamma radiation was recorded with a portable gamma-ray spectrometer RS 230 manufactured by Radiation Solutions, Ontario, Canada. The instrument uses a bismuth germinate (BGO) scintillation detector that, on account of higher material density, is about $50 \%$ more precise than portable units using a sodium iodide (NaI) detector with a crystal of the same size. Due to its small size ( $25 \mathrm{~cm}$ long, $10 \mathrm{~cm}$ wide), and light weight $(2 \mathrm{~kg})$ it is easy to carry and use in the field. Measurements were taken in the "assay-mode", i.e. each represented a single estimation of thorium and uranium (in ppm) and potassium (wt. \%) concentrations from the gamma-radiation spectrum. Coordinates of individual sites were recorded using a GPS connected to the spectrometer via Bluetooth. The instrument could be also useful for quick scanning of the total $\gamma$-radiation count of rocks, which is studied in its 'survey mode'.

Acqusition time of $120 \mathrm{~s}$ was chosen to allow sufficient time to establish a stable spectrum. The device integrates an area of $c .1$ meter in diameter with a depth of $c$. 15-25 cm (depending on material density) when in direct contact with the outcrop (Radiation Solutions 2009). The values used for stripping and background correction were provided by the manufacturer and are stored and applied in the spectrometer unit itself (Radiation Solutions 2009). The manufacturer used concrete pads of $1 \mathrm{~m} \times 1 \mathrm{~m} \times 30 \mathrm{~cm}$ size containing known amounts of potassium, uranium and thorium and a fourth pad with none of these three elements to measure the background for the instrument calibration (details in Grasty et al. 1991). During calibration by the manufacturer, spectra are accumulated over a time period of 5 minutes on the $\mathrm{K}, \mathrm{U}$ and Th pads, and 10 minutes on the Background pad with no radioelements (Radiation Solutions 2008). Then stripping ratios and sensitivity constants are computed following Grasty et al. (1991). These are finally saved in the device and utilized during field measurements to calculate the unknown wt. \% K, and ppm eU and eTh.

For interpretation of the calculated $\mathrm{K}, \mathrm{U}$ and Th concentrations, possible uncertainties during the data acquisition need to be taken into account. The three main error sources are: (i) statistical errors due to background noise during registration of the gamma rays, (ii) calibration errors and (iii) geometrical errors if the rock exposure strongly deviates from a homogenous half-space of material. Furthermore, possible cross interferences can occur as error components for a single element will also influence the remaining elements (Grasty et al. 1991; Radiation Solutions 2007).

For quality control of the gamma radiation (GR) data, comparison with geochemical data is necessary. Previously, we have substantiated the general significance of indirect GR measurements with the RS 230 equipment (Scharfenberg et al. 2019). This study showed good correlation of $U$ and $T h$ concentrations derived from in situ measurements and data measured by ICP-MS.

\subsection{Heat production}

For calculation of the radiogenic heat production (RHP) ( $A$ in $\mu \mathrm{W} / \mathrm{m}^{3}$ ), the radioelement concentrations from surface measurements are considered using the equation of Rybach (1988):

$$
A=10^{-5} \rho\left(9.52 c_{U}+2.56 c_{T h}+3.48 c_{K}\right)
$$

where $\rho$ is the density of the rock in $\mathrm{kg} / \mathrm{m}^{3}, c_{U}$ is the $\mathrm{U}$ concentration in ppm, $c_{T h}$ is the Th concentration in ppm, and $c_{K}$ is the $\mathrm{K}$ concentration in wt. \%. The heat production constants $(\mathrm{W} / \mathrm{kg})$ are 9.52 for $\mathrm{U}, 2.56$ for Th and 3.48 for K. These values reflect the contribution of each of the radioelements to the radiogenic heat production, which is highest in $\mathrm{U}$, followed by $\mathrm{Th}$ and K. Densities from the literature (if available) are used for the calculations (see Tab. 2). Otherwise, our own measurements in isopropanol, applying the buoyancy technique (Archimedes' principle), completed the database (Tab. 2).

For the Oberpfalz area (study area 2, Fig. 1b) we have included airborne GR measurements (Röttger et al. 1991) in addition to the in situ values. It has been shown (e.g. for the Cornubian geothermal province, Beamish and Busby 2016) that such data sets can be helpful to construct maps delineating the regional thermal structure. However airborne measurements cannot be compared directly with in situ ones. This is because the former are strongly influenced by attenuation of soil coverage, whereas for the latter, fresh outcrops are selected for data sampling. In order to overcome the generally large differences in calibration of GR facilities, Th concentrations obtained by both methods have been compared (Scharfenberg and de Wall 2016). They show a good linear correlation, and airborne data have been corrected accordingly for calculation and presentation of heat production data (Fig. 2a). For quality control, the corrected data are compared with other laboratory data (field laboratory of the Continental Deep Drilling Program, Windischeschenbach) and data from Falkenberg drillhole (Haack et al. 1991) located within this granite massif in vicinity to the survey area (Fig. 2b). 
Tab. 2 Compilation of gamma radiation data

\begin{tabular}{|c|c|c|c|c|c|c|c|c|c|c|c|}
\hline \multirow{2}{*}{ Intrusion complex } & \multirow{2}{*}{ Rock type } & \multirow{2}{*}{$\mathbf{N}$} & \multicolumn{2}{|c|}{ eK [\%] } & \multicolumn{2}{|c|}{ eU [ppm] } & \multicolumn{2}{|c|}{ eTh [ppm] } & \multirow{2}{*}{$\mathbf{T h} / \mathbf{U}$} & \multirow{2}{*}{$1 \sigma$} & \multirow{2}{*}{$\begin{array}{l}\text { density } \\
{\left[\mathrm{kg} \mathrm{m}^{3}\right]}\end{array}$} \\
\hline & & & Mean & $1 \sigma$ & Mean & $1 \sigma$ & Mean & $1 \sigma$ & & & \\
\hline \multicolumn{12}{|c|}{ Area 1: Fichtelgebirge(compiled from Scharfenberg et al. 2016) } \\
\hline Preceding intrusions & Redwitzites & 8 & 3.1 & 0.6 & 7.4 & 2.1 & 36.0 & 6.5 & 5.1 & 1.1 & $2850^{1}$ \\
\hline \multirow{5}{*}{ OIC } & G1 & 46 & 5.0 & 1.1 & 7.0 & 1.8 & 34.1 & 9.6 & 5.3 & 2.4 & $2680^{1}$ \\
\hline & G1R & 19 & 5.0 & 0.7 & 9.6 & 1.8 & 38.3 & 5.0 & 4.1 & 1.1 & $2670^{1}$ \\
\hline & G1S & 2 & 5.0 & nd & 7.9 & nd & 29.4 & nd & 3.8 & nd & $2640^{1}$ \\
\hline & G1HS & 18 & 5.4 & 0.6 & 10.6 & 3.1 & 19.0 & 7.0 & 2.1 & 1.3 & $2650^{1}$ \\
\hline & MEAN OIC & 93 & 5.1 & 0.2 & 8.8 & 1.4 & 30.2 & 7.2 & 3.8 & 1.1 & \\
\hline \multirow{6}{*}{ YIC } & G2 & 23 & 5.1 & 0.6 & 10.3 & 2.5 & 28.6 & 12.9 & 3.0 & 1.8 & $2640^{1}$ \\
\hline & G3 & 101 & 5.2 & 0.5 & 13.1 & 6.1 & 22.9 & 6.3 & 2.2 & 1.2 & $2644^{1}$ \\
\hline & $\mathrm{G} 2 \mathrm{~K}$ & 24 & 5.3 & 1.2 & 10.2 & 3.3 & 20.5 & 5.5 & 2.1 & 0.9 & $2650^{1}$ \\
\hline & G3K & 22 & 6.1 & 0.6 & 7.6 & 1.8 & 29.3 & 5.4 & 4.2 & 1.4 & $2660^{1}$ \\
\hline & G4 & 15 & 4.9 & 0.4 & 24.6 & 6.7 & 14.7 & 4.6 & 0.7 & 0.3 & $2650^{1}$ \\
\hline & MEAN YIC & 185 & 5.3 & 0.3 & 13.1 & 2.0 & 23.2 & 3.0 & 2.4 & 0.5 & \\
\hline \multicolumn{12}{|c|}{ Area 2: Oberpfalz } \\
\hline Preceding intrusions & Redwitzites & 3 & 2.8 & 0.1 & 2.9 & 0.5 & 17.6 & 0.4 & 6.3 & 1.4 & $2850^{1}$ \\
\hline \multirow{3}{*}{ OIC } & Leuchtenberg & 22 & 5.0 & 0.5 & 8.4 & 1.9 & 23.5 & 9.5 & 3.0 & 1.5 & $2630^{2}$ \\
\hline & Zainhammer & 6 & 5.9 & 0.5 & 7.6 & 2.6 & 22.2 & 5.8 & 3.6 & 2.4 & 2630 \\
\hline & MEAN OIC & 31 & 5.2 & 0.6 & 8.2 & 2.1 & 23.2 & 8.9 & 3.1 & 1.7 & \\
\hline \multirow{5}{*}{ YIC } & Falkenberg & 29 & 5.9 & 0.5 & 14.4 & 3.2 & 40.7 & 4.8 & 2.9 & 0.6 & $2600^{3}$ \\
\hline & Friedenfels & 14 & 4.8 & 0.4 & 14.1 & 3.5 & 9.6 & 1.0 & 0.7 & 0.2 & $2590^{2}$ \\
\hline & Steinwald & 33 & 4.6 & 0.5 & 21.2 & 7.4 & 4.5 & 1.2 & 0.2 & 0.1 & $2590^{2}$ \\
\hline & Flossenbürg & 18 & 5.7 & 0.5 & 27.9 & 16.4 & 21.9 & 2.7 & 1.1 & 0.6 & $2610^{2}$ \\
\hline & MEAN YIC & 94 & 5.3 & 0.6 & 19.4 & 5.7 & 19.2 & 13.9 & 1.2 & 1.0 & \\
\hline \multicolumn{12}{|c|}{ Area 3: Bavarian Forest } \\
\hline \multirow{3}{*}{ Hauzenberg Pluton } & Granodiorite & 58 & 4.62 & 0.64 & 4.72 & 2.16 & 21.71 & 10.66 & 4.77 & 1.7 & $2680^{4}$ \\
\hline & Hauzenberg II & 62 & 5.61 & 0.56 & 8.77 & 2.95 & 16.23 & 2.49 & 2.06 & 0.76 & $2660^{4}$ \\
\hline & Hauzenberg I & 61 & 5.89 & 0.4 & 9.83 & 2.65 & 24.18 & 6.36 & 2.64 & 1.03 & $2660^{4}$ \\
\hline Host rock & Granite (host rock) & 24 & 5.47 & 1.17 & 5.58 & 2.17 & 37 & 13.05 & 7.75 & 4.71 & $2660^{4}$ \\
\hline \multicolumn{12}{|c|}{ Fürstenstein Intrusive Complex } \\
\hline \multirow{2}{*}{ Diorites } & Bt Qtz Diorite & 12 & 4.4 & 0.95 & 6.2 & 1.86 & 24 & 6.98 & 4 & 0.63 & $2724^{4}$ \\
\hline & Hbl-Bt Diorite & 37 & 5.2 & 0.75 & 7.4 & 2.64 & 24.3 & 6.15 & 3.6 & 1.43 & $2641^{4}$ \\
\hline \multirow{4}{*}{ Granites } & Tittling Granite & 22 & 4.8 & 0.39 & 7.6 & 1.90 & 28.9 & 3.96 & 4 & 0.80 & $2695^{4}$ \\
\hline & Saldenburg Granite & 89 & 5.6 & 0.67 & 8.5 & 2.92 & 56.7 & 12.63 & 7.4 & 2.68 & $2669^{4}$ \\
\hline & Eberhardsreuth Granite & 10 & 4.8 & 0.27 & 4.3 & 0.87 & 24.2 & 2.35 & 5.9 & 1.49 & $2653^{4}$ \\
\hline & Two-mica Granite & 41 & 4.6 & 1.02 & 5.4 & 1.60 & 27.1 & 5.02 & 5.3 & 1.45 & $2657^{4}$ \\
\hline
\end{tabular}

The prefix e-indicates an indirect detection of $U$ and Th by means of gamma rays emitted by their decay products;

nd: not determined.

Density: ${ }^{1}$ Hecht et al. (1997); ${ }^{2}$ cited in Siebel et al. (1997); ${ }^{3}$ own measurements, ${ }^{4}$ literature data for density of the Falkenberg Granite range between 2620 and 2590.

Data of individual measurements, including GPS coordinates for sampling sites, are included in the Electronic Supplementary Material (ESM 1)

\section{Results}

\subsection{Natural gamma radiation of granites}

Uranium and thorium concentrations as well as $\mathrm{Th} / \mathrm{U}$ ratios are useful parameters in the characterization of granitic rocks (Artemieva et al. 2017). Both are incompatible elements, with Th slightly more incompatible than $\mathrm{U}$ in major silicates (Kirkland et al. 2015). During partial melting, their ratio does not change significantly and thus $\mathrm{Th} / \mathrm{U}$ ratios often reflect source variations.
The granite intrusions show differences in total radiation and distinct concentrations and ratios of the radiogenic elements between the three areas (Tab. 2). The $U$ concentrations in the Fichtelgebirge (7 to 13 ppm) and the Bavarian Forest (4 to $10 \mathrm{ppm}$ ) are comparable, except for G4 (Tin Granite, Fichtelgebirge) reaching $25 \mathrm{ppm}$. Compared to the two other areas, the Oberpfalz granitoids are characterized by more variable and higher U content (8-22 ppm; Tab. 2). The YIC granites tend to have higher $\mathrm{U}$ concentrations than the OIC ones (Tab. 2). The Th content in all granites is less 


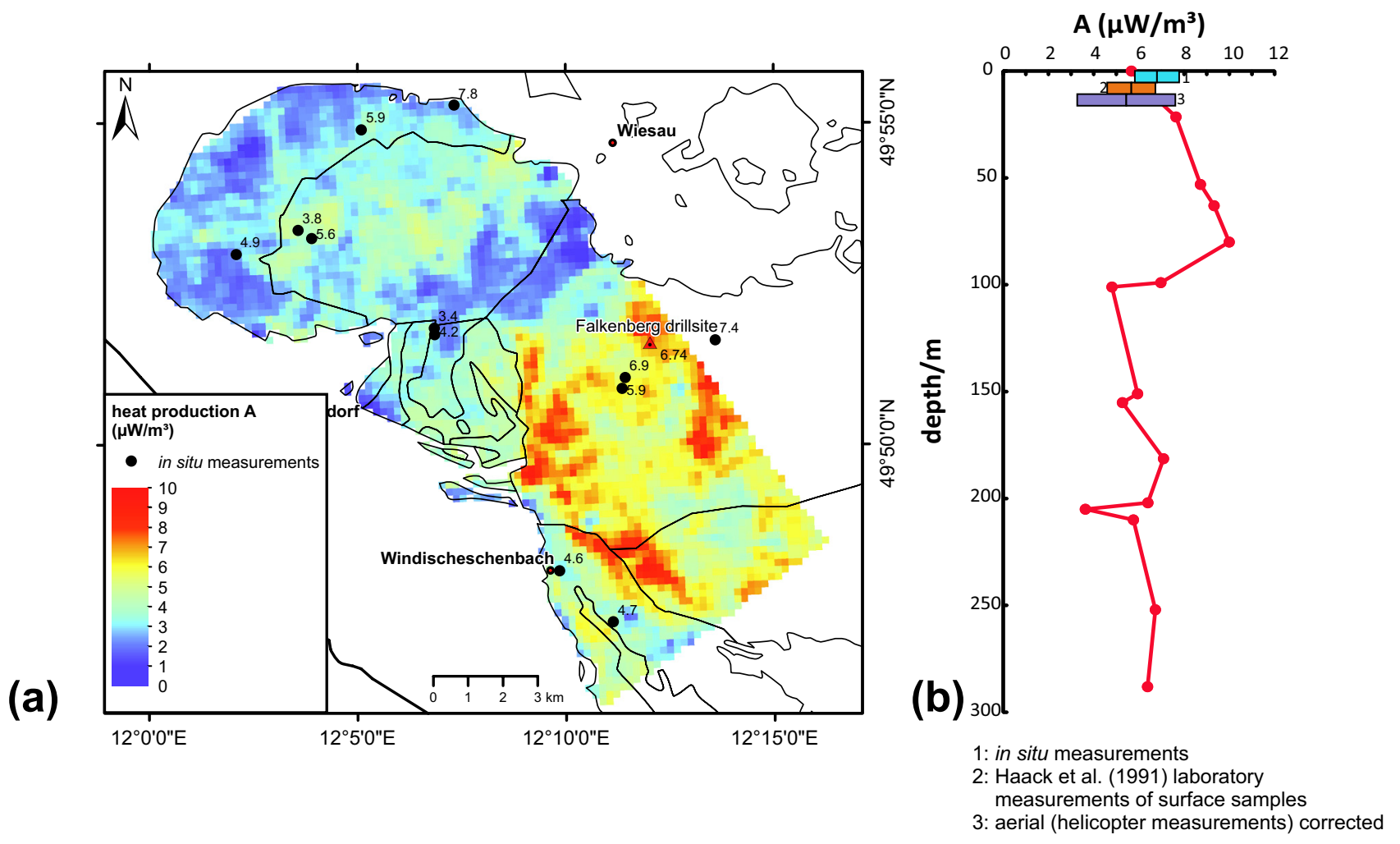

Fig. 2a - Heat production calculated from airborne radiometric survey after data correction (Scharfenberg and de Wall 2016). b - Heat production rate vs. depth for the Falkenberg Granite (area 2, Fig. 1b) calculated from laboratory measurements on drill cores (Haack et al. 1991). Measurements in the upper borehole section are compared with surface measurements (Haack et al. 1991), in situ gamma-ray measurements (this study) and corrected data from the airborne survey (Scharfenberg and de Wall 2016).

than $40 \mathrm{ppm}$ except for the Saldenburg intrusion in the Bavarian Forest that has significantly higher mean Th content (56.7 ppm; Tab. 2).

Differences in the radiogenic signature are best displayed in binary plots of Th vs. $U$ for the three areas studied (Fig. 3). All granite batches related to the Fichtelgebirge Pluton (area 1), except for the youngest intrusion (G4) and all the granites in the Bavarian Forest (area 3 ), are characterized by Th/U ratios exceeding 1 . In contrast, the pattern is more variable for the Oberpfalz (area 2). Here, the older granites (Leuchtenberg, Zainhammer) and the Falkenberg Granite (the oldest granite in the YIC; Tab. 1) plot in the Th/U > 1 field, whereas the younger granites (Friedenfels, Steinwald and Flossenbürg) have higher $\mathrm{U}$ and lower Th values with $\mathrm{Th} / \mathrm{U}<1$.

The Th vs. Th/U plot for the three areas displays a single cluster and defines a linear positive trend (Fig. 4a). The Fichtelgebirge granites reach lower values than the Bavarian Forest granites (Fig. 4b). The Oberpfalz granites are the most variable, showing also the lowest values (Fig. 4c). The Bavarian Forest granites yield the highest $\mathrm{Th} / \mathrm{U}$ ratios and $\mathrm{Th}$ concentrations (Fig. 4d).

\subsection{Radiogenic heat production}

\subsubsection{Variability of heat production}

The radiogenic heat production was calculated using the formula of Rybach (1988) considering differences in density of the granitoids (Tab. 2). Statistic parameters are shown in Tab. 3. We classified the heat potential of the studied intrusive rocks into low-, moderate-, and highheat-producing granites (Fig. 5). For this classification, we have used a lower limit of $4 \mu \mathrm{W} / \mathrm{m}^{3}$ for moderate and $8 \mu \mathrm{W} / \mathrm{m}^{3}$ for high heat productions, respectively. These thresholds follow the scheme established by Huston ed. (2010) for granitic intrusions in Queensland, Australia.

In our case, granites from the older intrusive suites in areas 1 and 2 are characterized by heat production rates of $4-6 \mu \mathrm{W} / \mathrm{m}^{3}$ and thus fall into the lower sector of moderate-heat-producing granites (Fig. 5). Average heat production rates of 4.8 and $4.0 \mu \mathrm{W} / \mathrm{m}^{3}$ are calculated for older granites of areas 1 and 2; the averages for the younger granites in these areas are slightly higher (5.5 for the area 1 and $6.5 \mu \mathrm{W} / \mathrm{m}^{3}$ for the area $2-\mathrm{Tab}$. 3). The intrusive complexes studied in Bavarian Forest (area 3) cannot be assigned to either older or younger complexes. 


\section{Area 1: Fichtelgebirge}

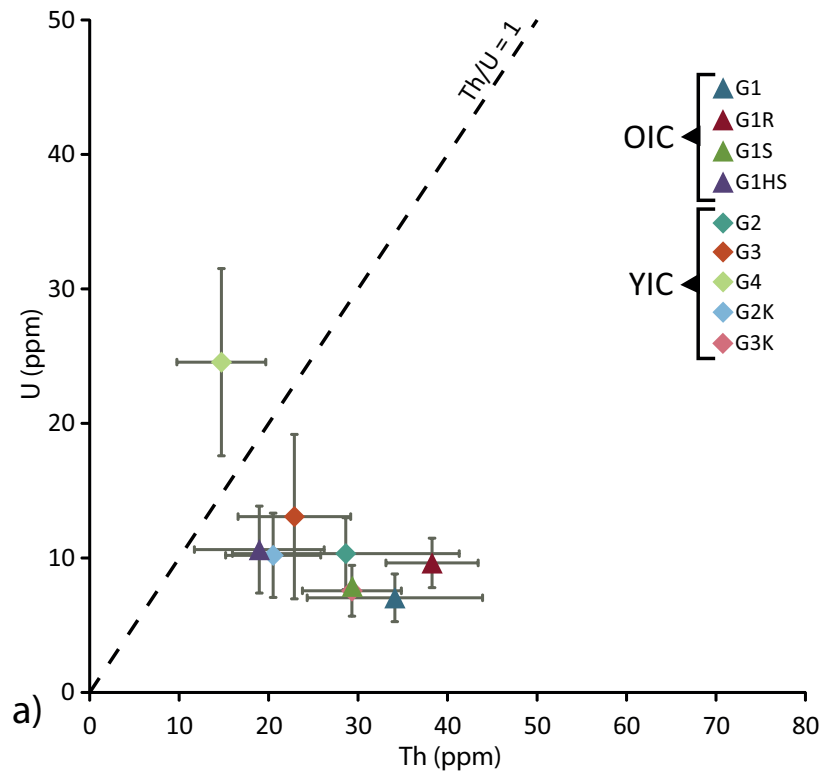

Area 3: Bavarian Forest

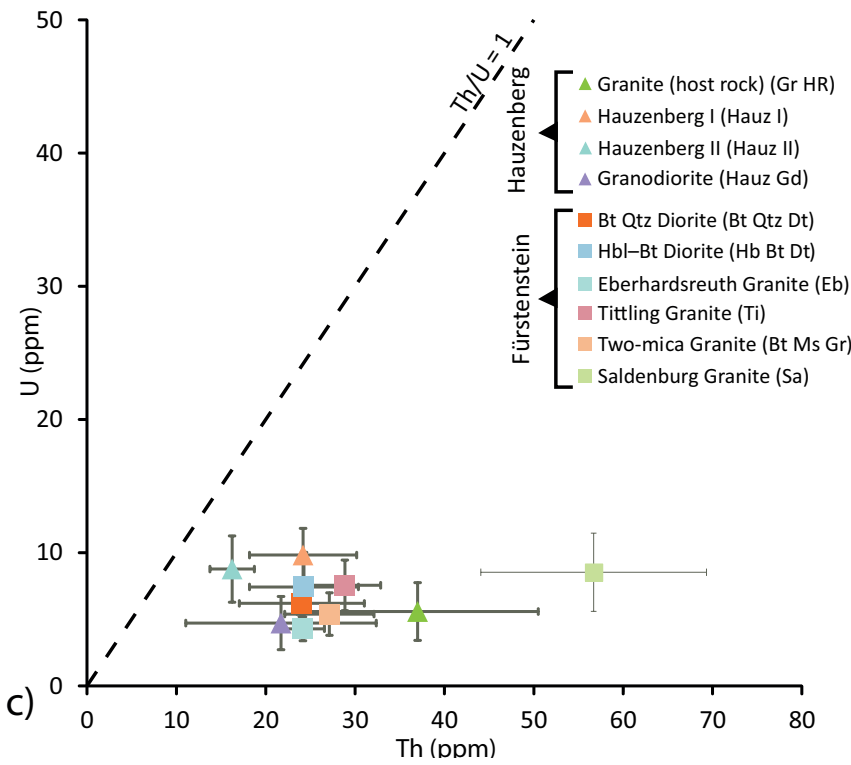

\subsubsection{Heat production distribution}

The data from the 829 assays have been used for construction of heat production maps (Fig. 6). In the maps the average RHP values (Tab. 3), are used for defining heat production ranges. The average values show a wide spread between less than 2.5 and more than 7.5 $\mu \mathrm{W} / \mathrm{m}^{3}$. The maps visualize the RHP variability within studied granitic areas and highlight regions of high heat production. All three studied areas contain some granites with elevated RHP. In the Fichtelgebirge, the G4 granite has values greater than $7 \mu \mathrm{W} / \mathrm{m}^{3}$ (Fig. 6 , area 1); however, with an exposed area of $15 \mathrm{~km}^{2}$ this type of granite covers only a minor part of the

\section{Area 2: Oberpfalz}

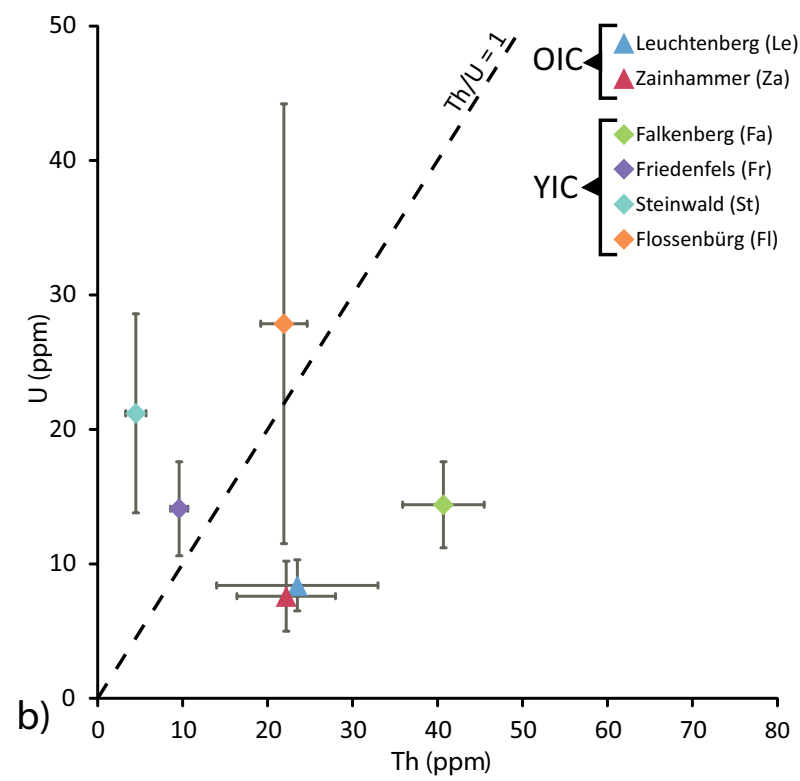

Fig. 3 Variation of average $\mathrm{Th}$ and $\mathrm{U}(\mathrm{ppm})$ concentrations with standard deviation $( \pm 1 \sigma)$ for the studied areas inferred from in situ gamma radiation measurements (for data, see Tab. 2). Area 1 lies within the Saxothuringian Zone (a); Area 2 comprises Oberpfalz granites in the transition zone (b); Area 3 represents granites from the Bavarian Forest and is part of the Moldanubian Zone of the Variscides (c).

Smrčiny-Fichtelgebirge Composite Massif (less than $250 \mathrm{~km}^{2}$ ). In the Oberpfalz area, the Flossenbürg and the Falkenberg granites with average RHP of $8.9 \mu \mathrm{W} /$ $\mathrm{m}^{3}$ and $6.8 \mu \mathrm{W} / \mathrm{m}^{3}$ cover larger areas of $54 \mathrm{~km}^{2}$ and $98 \mathrm{~km}^{2}$, respectively. These intrusions have to be considered as volumetrically significant heat-producing bodies. Youngest intrusion within the Fürstenstein Intrusive Complex in the Bavarian Forest is the highheat-producing Saldenburg granite $\left(6.6 \mu \mathrm{W} / \mathrm{m}^{3}\right)$. The exposed area $\left(87 \mathrm{~km}^{2}\right)$ of this granite type accounts for $70 \%$ of the whole Complex. However, these exposed areas represent the present erosional level and for an estimate of the total heat contribution, volumetric constraints are needed. 
Tab. 3 Calculated heat production for intrusions in the studied areas

\begin{tabular}{|c|c|c|c|c|c|c|c|c|c|}
\hline \multirow[b]{2}{*}{ Intrusion complex } & \multirow[b]{2}{*}{ Rock type } & \multirow[b]{2}{*}{$\mathbf{N}$} & \multicolumn{2}{|c|}{ Mean value (Fig. 6) } & \multicolumn{5}{|c|}{ Boxplot (Fig. 5)** } \\
\hline & & & $\mathbf{A}\left(\boldsymbol{\mu} \mathbf{W} \mathbf{m}^{-3}\right)$ & $1 \sigma$ & $\min$ & $\max$ & Median & $\mathbf{L Q}$ & $\mathbf{U Q}$ \\
\hline \multicolumn{10}{|c|}{ Area 1: Fichtelgebirge* } \\
\hline Preceding intrusions & Redwitzite (diorites) & 8 & 4.95 & 1.03 & nd & nd & nd & nd & nd \\
\hline \multirow{5}{*}{ OIC } & G1 & 46 & 4.60 & 0.65 & 3.29 & 5.85 & 4.40 & 4.14 & 5.18 \\
\hline & G1R & 19 & 5.52 & 0.70 & 4.49 & 6.95 & 5.40 & 4.99 & 6.12 \\
\hline & G1S & 2 & 4.42 & nd & nd & nd & nd & nd & nd \\
\hline & G1HS & 18 & 4.46 & 0.64 & 3.45 & 4.63 & 4.51 & 4.01 & 4.74 \\
\hline & MEAN OIC & 93 & 4.75 & 0.45 & & & & & \\
\hline \multirow{6}{*}{ YIC } & $\mathrm{G} 2$ & 23 & 5.22 & 0.73 & 3.44 & 6.37 & 5.30 & 4.70 & 5.85 \\
\hline & G3 & 101 & 5.32 & 1.57 & 2.31 & 9.57 & 5.07 & 4.31 & 6.26 \\
\hline & $\mathrm{G} 2 \mathrm{~K}$ & 24 & 4.55 & 0.87 & 3.52 & 6.54 & 4.38 & 4.01 & 4.69 \\
\hline & G3K & 22 & 4.47 & 0.53 & 3.20 & 5.27 & 4.61 & 4.23 & 4.81 \\
\hline & G4 & 15 & 7.64 & 1.85 & 4.19 & 10.63 & 7.86 & 6.69 & 8.90 \\
\hline & MEAN YIC & 185 & 5.55 & 1.81 & & & & & \\
\hline \multicolumn{10}{|c|}{ Area 2: Oberpfalz } \\
\hline \multirow[t]{2}{*}{ Preceding intrusions } & Redwitzite (diorites) & 3 & 2.40 & 0.10 & nd & nd & nd & nd & nd \\
\hline & Leuchtenberg & 22 & 4.10 & 0.70 & 2.66 & 5.62 & 4.21 & 3.52 & 4.55 \\
\hline \multirow[t]{2}{*}{ OIC } & Zainhammer & 6 & 3.90 & 0.60 & 2.83 & 4.92 & 3.99 & 3.76 & 4.11 \\
\hline & MEAN OIC & 31 & 4.00 & 0.10 & & & & & \\
\hline \multirow{5}{*}{ YIC } & Falkenberg & 29 & 6.80 & 1.00 & 4.77 & 8.35 & 7.02 & 6.11 & 7.55 \\
\hline & Friedenfels & 14 & 4.50 & 0.90 & 2.87 & 6.23 & 4.35 & 3.89 & 5.29 \\
\hline & Steinwald & 33 & 6.00 & 1.80 & 3.27 & 10.74 & 5.83 & 4.44 & 7.16 \\
\hline & Flossenbürg & $18(26)^{*}$ & 8.90 & 4.00 & 3.87 & 16.89 & 8.00 & 5.49 & 12.93 \\
\hline & MEAN YIC & 94 & 6.50 & 1.60 & & & & & \\
\hline \multicolumn{10}{|c|}{ Area 3: Bavarian Forest } \\
\hline \multirow{5}{*}{ Hauzenberg Pluton } & Granodiorite & 58 & 3.12 & 1.28 & 1.14 & 4.88 & 3.79 & 1.70 & 4.21 \\
\hline & Hauzenberg II & 62 & 3.85 & 0.82 & 2.50 & 5.48 & 6.62 & 3.26 & 4.51 \\
\hline & Hauzenberg I & 61 & 4.68 & 0.76 & 3.34 & 7.17 & 4.58 & 4.14 & 5.10 \\
\hline & Granite (host rock) & 24 & 4.44 & 1.12 & 0.89 & 6.59 & 4.65 & 3.70 & 4.97 \\
\hline & Mean & 181 & 3.88 & & & & & & \\
\hline \multicolumn{10}{|c|}{ Fürstenstein Intrusive Complex (FIC) } \\
\hline \multirow{7}{*}{ Early intrusions } & Bt Qtz Diorite & 12 & 3.90 & 0.89 & 2.38 & 5.51 & 3.36 & 2.99 & 4.53 \\
\hline & Hbl-Bt Diorite & 37 & 4.00 & 0.83 & 2.60 & 6.36 & 4.02 & 3.49 & 4.57 \\
\hline & Tittling Granite & 22 & 4.40 & 0.69 & 3.08 & 6.04 & 4.39 & 3.80 & 4.82 \\
\hline & Saldenburg Granite & 89 & 6.55 & 1.24 & 4.52 & 10.37 & 6.38 & 5.54 & 7.32 \\
\hline & Eberhardsreuth Granite & 10 & 3.20 & 0.26 & 2.54 & 3.50 & 3.24 & 3.03 & 3.32 \\
\hline & Bt-Ms Granite & 41 & 3.70 & 0.69 & 2.39 & 5.31 & 3.62 & 3.07 & 4.13 \\
\hline & Mean FIC & 211 & 4.24 & 1.10 & & & & & \\
\hline
\end{tabular}

* Excluding measurements from U-enriched fault planes

** min (minimun) and max (maximum) refer to lowest and highest values, median to $50 \%$, LQ to first quartile (25 \%), UQ to third quartile (75\%) of data distribution

Data of individual measurements including coordinates for sampling sites are available in the Electronic Supplementary material (ESM 1)

\section{Discussion}

\subsection{Th and $U$ variations}

The average $\mathrm{Th} / \mathrm{U}$ ratio of the continental crust is estimated at c. 4 (Rudnick et al. 1998; McLennan and Taylor 1996; Jaupart and Mareschal 2003) and igneous rocks have on average $\mathrm{Th} / \mathrm{U}$ ratios between 3 and 4 for most values of
$\mathrm{SiO}_{2}$, even though rocks with a low silica content show a larger variability (Hasterok et al. 2018). Globally, there is a variation in the $\mathrm{Th} / \mathrm{U}$ ratio in felsic rocks between less than 1 and over 10 (Hasterok et al. 2018). Mafic magmatic rocks have a slightly lower $\mathrm{Th} / \mathrm{U}$ ratio compared with the felsic ones. Zircons from a range of mafic to felsic samples show a similar trend in $\mathrm{Th} / \mathrm{U}$ ratios (Kirkland et al. 2015). While this trend is statistically significant, the variation 

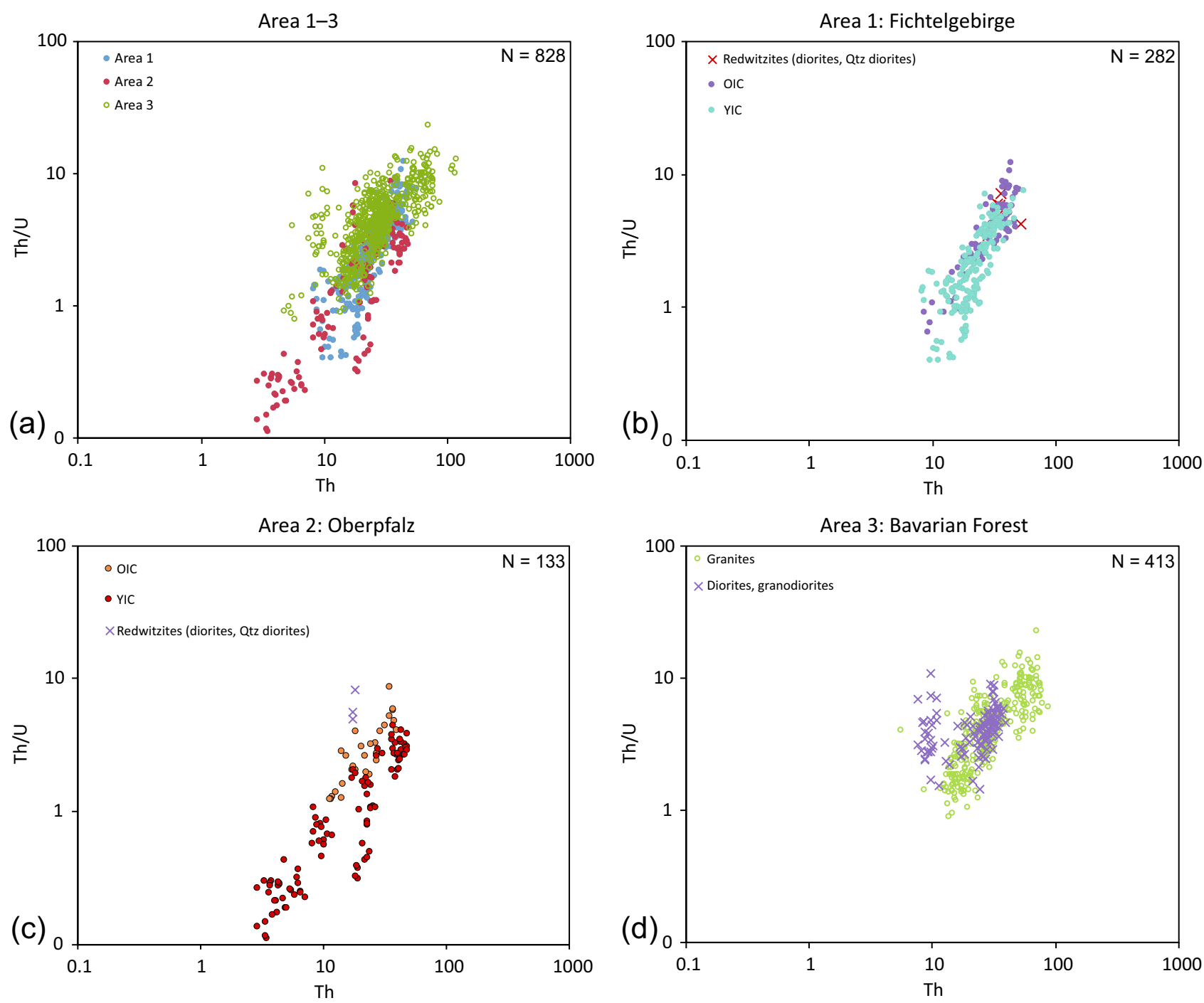

Fig. 4 Plots of $\mathrm{Th} / \mathrm{U}$ ratios versus Th concentrations for granitoids from the Western Bohemian Massif. a - Areas 1-3; b - Area 1: Fichtelgebirge; c - Area 2: Oberpfalz; d - Area 3: Bavarian Forest.

is relatively small with respect to the natural variability. Overall, a constant $\mathrm{Th} / \mathrm{U}$ ratio of $c .4$ in granites seems to give a reasonable estimate for the $\mathrm{U}$ and $\mathrm{Th}$ concentrations (e.g. Artemieva et al. 2017; Hasterok et al. 2018).

This study shows that the $\mathrm{Th} / \mathrm{U}$ ratio can vary over two orders of magnitude even within one area (Fig. 4) implying that source heterogeneities are greater than previously assumed. The variation in $\mathrm{Th} / \mathrm{U}$ ratios as well as Th and $\mathrm{U}$ concentrations caused by different source compositions and degree of melting may be further modified by fractional crystallization, fluid mobilization and/or magma mixing. However, except for the redwitzites, the magma mixing does not seem to have occurred on a major scale in the studied area (Hecht et al. 1997; Chen et al. 2003; Siebel and Chen 2010). The Th and $U$ heterogeneities had to be partly inherited from the source, because the spread in $\mathrm{Th} / \mathrm{U}$ ratios is too large to be explained by degree of melting, fractional crystallization or fluid mobilization processes alone. This is especially the case for intrusions of different ages or locations (see Tabs 1-2). As Th is more incompatible than $U$, more enriched sources have higher $\mathrm{Th} / \mathrm{U}$ ratios and $\mathrm{Th}$ concentrations. This could imply that the granitoids from the Bavarian Forest and the Fichtelgebirge have on average more enriched sources compared to those from the Oberpfalz. The extremely low $\mathrm{Th} / \mathrm{U}$ ratios (below unity) in the Oberpfalz granites, if compared to the other two regions, are mainly due to high $\mathrm{U}$ and low $\mathrm{Th}$ concentrations (Fig. 3).

However, fractional crystallization of accessory minerals, especially zircon and monazite, but also xenotime, could have added to the variation of these granites (e.g. Miller and Mittlefehldt 1982; Hecht et al. 1997, 1999; Chen et al. 2003; Siebel and Chen 2010), contributing to the trend in Fig. 4. The fractionation of monazite lowers 

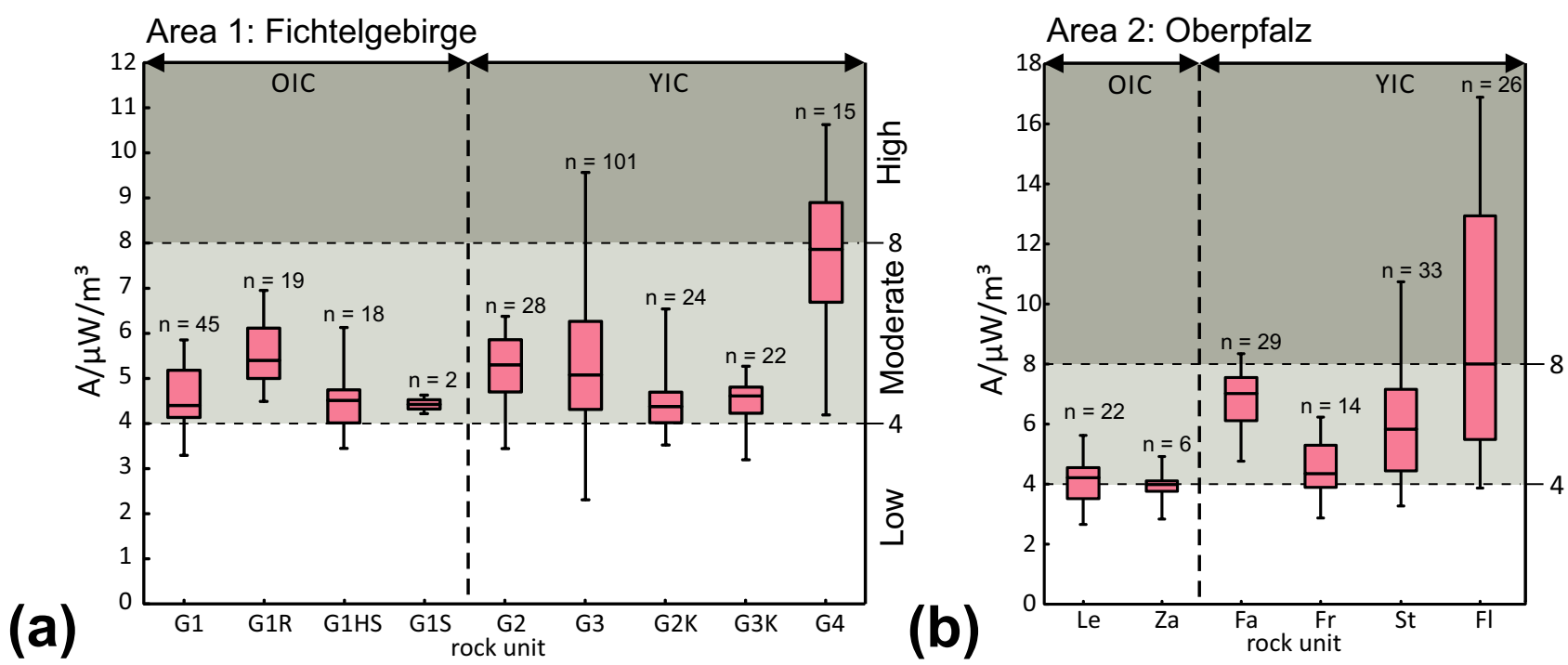

Area 3: Bavarian Forest

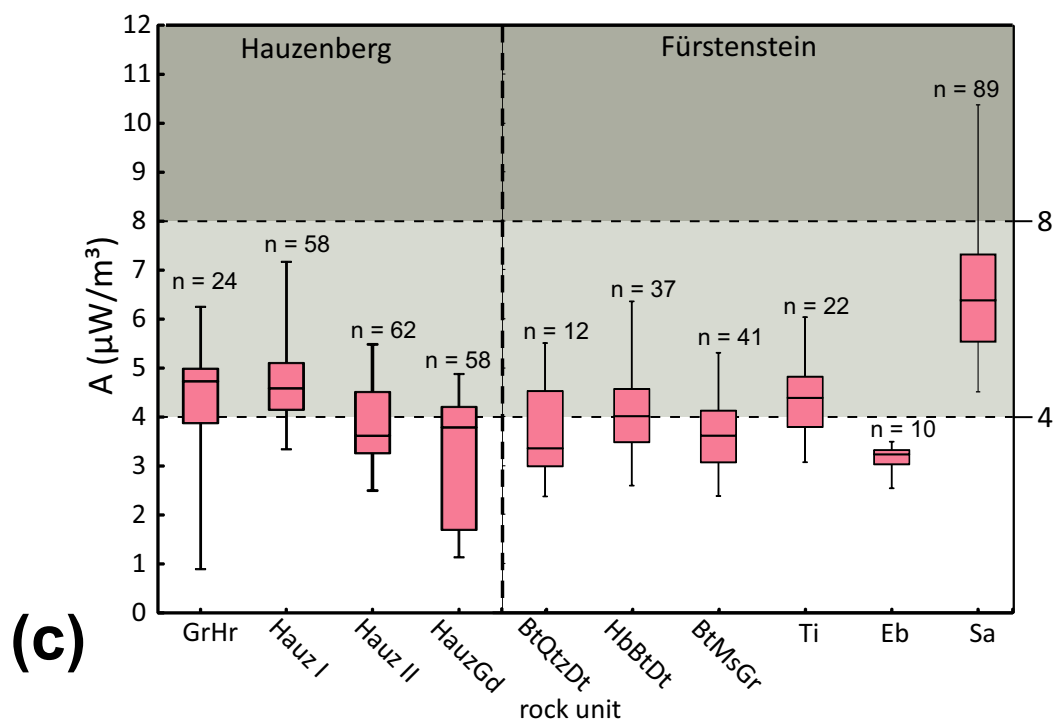

Fig. 5 Box-plots showing the variation in heat production of Variscan granites in the western Bohemian Massif. For abbreviations, see Tabs 1 and 2.

both the $\mathrm{Th} / \mathrm{U}$ ratio and the Th concentration. In contrast, zircon fractionation increases the $\mathrm{Th} / \mathrm{U}$ ratio, because zircon has very high $U$ concentrations. This could explain the spread within individual intrusions of the same age and source. For instance, the high $\mathrm{Th} / \mathrm{U}$ ratios of the diorites from the Bavarian Forest are probably due to zircon fractionation (Fig. 4).

Hydrothermal vein-type, fault-, and shear zone-hosted uranium deposits are widespread in the Variscan Belt of Mid-Europe (Kříbek et al. 2009 and references therein). As the Oberpfalz granites have intruded along fault intersections with the Moldanubian-Saxothuringian contact zone and as their low Th concentrations point to a depleted source, it is possible that the high U concentrations are due to $\mathrm{U}$ remobilization. Paleozoic shales could be the source of the uranium (Romer and Cuney 2018). Fluid mobilization can change the U, but does not affect the Th concentrations. The reason is that the $\mathrm{U}$ is far more mobile because of metamictization and increased solubility in oxidized environment, where it forms an uranyl anion. In contrast, Th remains firmly bound in the crystal lattice.

Interestingly, the YIC of the Fichtelgebirge and the Oberpfalz tend to have lower $\mathrm{Th} / \mathrm{U}$ ratios compared to the OIC granites and are therefore less enriched. This hints to different sources of the OIC and YIC. Here the low $\mathrm{Th} / \mathrm{U}$ ratios are mostly due to high $\mathrm{U}$ concentrations (average $U$ concentrations in the OIC are less, and in the YIC more than $10 \mathrm{ppm}$. The high $\mathrm{U}$ concentrations are probably due to $\mathrm{U}$ remobilization. Addition or removal of $U$ does have a much larger impact on samples with low Th concentrations, but could partly also have affected those with higher Th and $\mathrm{U}$ concentrations. 
Area 1: Fichtelgebirge

(a)

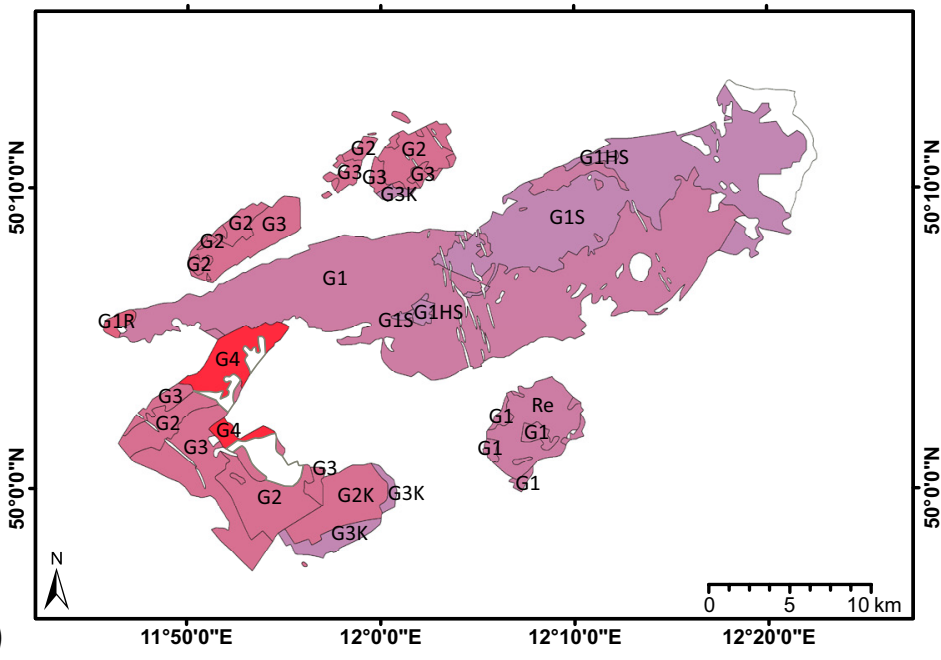

Area 3: Bavarian Forest

(c)

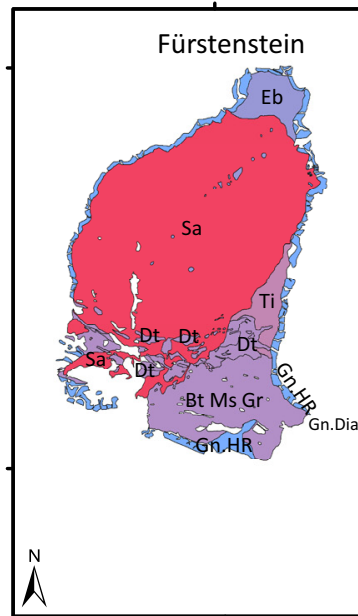

Area 2: Oberpfalz

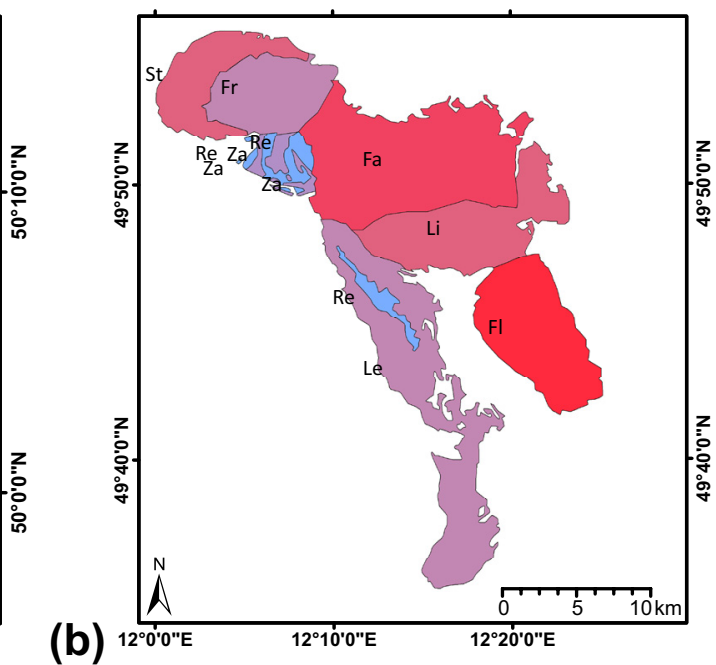

Fig. 6 Distribution of the mean heat production for the studied granitic complexes in the three studied granite areas. For Area 2, airborne measurements (Fig. 2) have been implemented. For abbreviations of rock units, see Tab. 2.

\subsection{Heat-producing classification and comparison with other granitic terrains}

Variable average and median values of RHP in granites can be found in the literature, e.g. $2.83 \mu \mathrm{W} / \mathrm{m}^{3}$ and 2.43 $\mu \mathrm{W} / \mathrm{m}^{3}$ (Vilà et al. 2010) or $3.54 \mu \mathrm{W} / \mathrm{m}^{3}$ and $2.79 \mathrm{~W} /$ $\mathrm{m}^{3}$ (Hasterok and Webb 2017). The difference is due to variations in age and petrogenetic setting within the compiled data sets. Artemieva et al. (2017) calculated an average of $2.79 \mu \mathrm{W} / \mathrm{m}^{3}$ for Phanerozoic granites worldwide, while Proterozoic granites show higher and widespread values of $3.83 \pm 2.14 \mu \mathrm{W} / \mathrm{m}^{3}$. However, most of the data considered by Artemieva et al. (2017) were derived from high-heat-producing, A-type granites of Australia (Neumann et al. 2000; McLaren et al. 2005;
Hasterok and Gard 2016) and thus might not be representative. A-type granites (Loiselle and Wones 1979; Eby 1992) are typical of intra-plate, often anorogenic settings. They are the most abundant in Proterozoic terranes, such as the Malani Igneous suite in NW India (Eby and Kochhar 1990; de Wall et al. 2018), and are characterized by generally high radioelement concentrations (Scharfenberg et al. 2015, 2019) resulting in higher RHP (Singh and Vallinayagam 2012). Therefore A-type granites commonly rank to high-heat-producing granites (HHP granites).

Here, we show that granites from the western margin of the Bohemian Massif display a large spread in RHP (see Tab. 3). Averages range 3.9-8.9 $\mu \mathrm{W} / \mathrm{m}^{3}$ and median values $3.2-8.0 \mu \mathrm{W} / \mathrm{m}^{3}$. Such variations can 

diogenic-heat production (RHP) data obtained in this study shows a bell-shaped distribution, with only slightly asymmetric shape skewed towards higher values. Average value and $1 \sigma$ standard deviation are calculated based on 829 measurements.
Fig. 7 Frequency histogram of all ra-

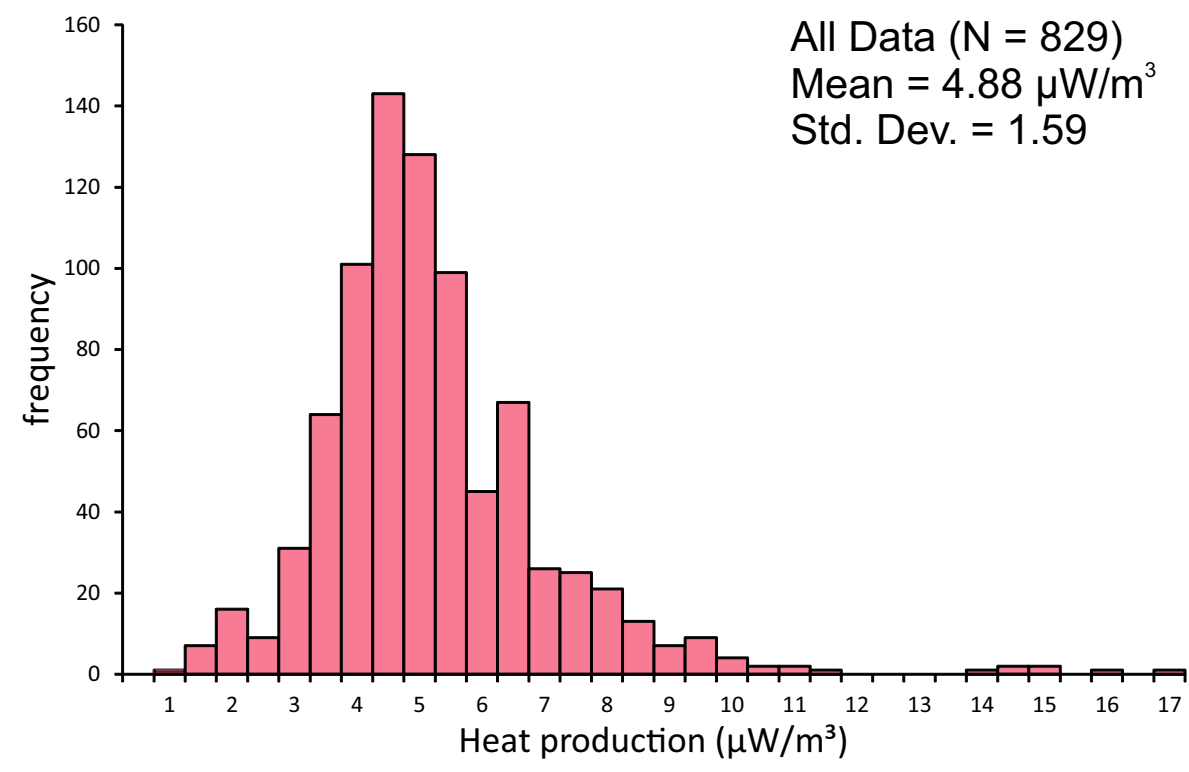

be either related to different source rocks, or distinct petrogenesis (Vilà et al. 2010; Artemieva et al. 2017), including fractionation of felsic magma as has been reported for the Fichtelgebirge and Oberpfalz granites (Hecht et al. 1997; Siebel et al. 1997). Precursors of the granites, the redwitzites (diorites), are predominately metaluminous and interpreted as mantlederived mafic magma (Kováŕíková et al. 2007). For the OIC, a contribution of melt from deeper sources is considered and these granites range from S-type to transitional I-/S-type (Siebel et al. 1997, 2003 and references therein).

For redwitzites in the Fichtelgebirge, the mean RHP is higher $\left(4.95 \mu \mathrm{W} / \mathrm{m}^{3}\right)$ than in the Oberpfalz granites $\left(2.40 \mu \mathrm{W} / \mathrm{m}^{3}\right)$. The RHP of $4.8 \mu \mathrm{W} / \mathrm{m}^{3}$ for OIC granites in the Fichtelgebirge and $5.3-5.6 \mu \mathrm{W} / \mathrm{m}^{3}$ for YIC units fall in the same range as reported for I- to S-type granites in the Erzgebirge (Förster and Förster 2000; Scharfenberg et al. 2016). A-type granites with RHP > $10 \mu \mathrm{W} / \mathrm{m}^{3}$ reported from other areas in the Bohemian Massif (Förster and Förster 2000; Breiter 2012) are not exposed in the studied areas. Nevertheless some of the measured granites display high RHP values, e.g. the $\mathrm{G} 4$ intrusion $\left(7.6 \mu \mathrm{W} / \mathrm{m}^{3}\right)$ a fluorine-enriched Tin Granite in the Fichtelgebirge (area 1; Irber et al. 1997; Förster et al. 2008). Furthermore some of the Oberpfalz granites emplaced along the MoldanubianSaxothuringian suture zone (area 2) are characterized by higher $\mathrm{U}$ concentrations resulting in $\mathrm{Th} / \mathrm{U}<1$. There is indication for general $\mathrm{U}$ enrichment along this lineament, associated with carbon-rich sedimentary units and mobilization during hydrothermal processes (Bültemann 1979; Stettner 1979; Dill and Weiser 1981). High U-values are typical of the Flossenbürg intrusion. The long axis of the oblong shape of this intrusion is parallel to the late-Variscan faults and such setting might have caused the remobilisation of $U$ as described above. Krušné hory granites in continuation of the suture line into the Czech Republic also show $\mathrm{Th} / \mathrm{U}<1$ due to elevated $\mathrm{U}$ concentrations of 10 to 27 ppm (Krešl et al. 1978).

In the Bavarian Forest, higher RHP values of the Saldenburg Granite are related to the high Th concentrations in this latest pulse of the large composite Fürstenstein Massif (Chen and Siebel 2004). The high Th concentrations can be explained by abundance of monazite crystallized during this late-stage granite formation.

There is no consensus on the RHP threshold to qualify granite as a HHP one. The most intensely studied area for geothermal potential is Australia. Based on a large data set on RHP of igneous rocks in Queensland, granites with values greater than $5 \mu \mathrm{W} / \mathrm{m}^{3}$ were considered as HHP granites (Siégel et al. 2012). However, a report on the assessment of geothermal potential in North Queensland (Huston ed. 2010) proposed a threshold of $8 \mu \mathrm{W} / \mathrm{m}^{3}$ for high-heat-producing granites and a range of 4 to $8 \mu \mathrm{W} /$ $\mathrm{m}^{3}$ for moderate-heat-producing granites.

Based on the radioelement concentrations from all 829 assays over the three areas studied in this project, a mean RHP of $4.9 \pm 1.8 \mu \mathrm{W} / \mathrm{m}^{3}$ is calculated (Fig. 7). In summary, it can be stated that the Variscan granites along the Western Bohemian Massif can be regarded as moderate- to high-heat-producing, whereby RHP values in the granites of the Saxothuringian and the transition zone (areas 1,2) are slightly higher than those in the Bavarian Forest (area 3). Taken together, the detailed heat production data provided here complement the existing compilations for heat production of granites in the Bohemian Massif (Klomínský et al. 2010), with attendant implications for further thermal modelling. 


\subsection{Consequences for regional tectono- -magmatic processes}

Melting of continental crust, migration and emplacement of granitic melts is the most important mechanism for enrichment and redistribution of heat-producing elements (HPE) in the middle and upper crust (e.g. Sandiford and McLaren 2002 and references therein). Sandiford et al. (2002) emphasized that long-term temperature changes due to redistribution of HPEs occur over timescales appropriate to the conductive response of the lithosphere, while on shorter timescales the temperature field will include thermal transients. The large volumes of granitoids that have intruded the continental crust in the late phase of the Variscan Orogeny must have caused an immense thermal pulse related to (i) heat transfer by the granitic melts into the host rocks and (ii) subsequent heat generation by in situ decay of radiogenic elements in already emplaced granitoid plutons. Magma ascent would always preferentially follow zones of weakness within the Earth's crust and emplacement of granitoids into shear zones can facilitate and trigger rapid exhumation of orogens (Faccenda et al. 2008; Závada et al. 2018; Tiwari and Biswal 2019). This has also been inferred for rapid exhumation of Variscan crustal blocks in the Bohemian Massif, e.g. by melt-controlled strain softening during uplift of Moldanubian rocks along the Central Bohemian Shear Zone (Scheuvens and Zulauf 2000).

Heat generation by decay of radiogenic elements can result in high internal heat production especially in thickened continental crust. During continent-continent collision the thickness of the continental crust in orogenic belts can exceed $60 \mathrm{~km}$ instead of 25-30 $\mathrm{km}$, typical of a buoyancy-equilibrated crust. Stacking of crustal slices enriched in RHP elements by tectonic or magmatic processes and the thermal conductivity profile are first-order parameters determining the thermal structure and gravitational instability of the crust (e.g. Gerya et al. 2002). The insulation of underlying fertile radiogenic crust by overlaying lithological units with relatively lower thermal conductivity is important for heat storage in the crust. Dörr and Zulauf (2010) proposed that the Variscan Bohemian Plateau was covered with unmetamorphosed Palaeozoic strata. The siliciclastic and carbonate units (Tasáryová et al. 2018 and references therein) could have formed an insulating cover, which would result in an increase in thermal gradients (Meixner et al. 2014; de Wall et al. 2019). Models by Bea (2012) showed that a thickened continental crust with an overall annual heat production greater than $1.2 \mu \mathrm{W} / \mathrm{m}^{3}$ is able to produce granitic melts after 30 to $40 \mathrm{Myr}$. Thus, radiogenic heating might have even been a dominant heat source in parts of the Variscan Orogen, potentially having a major influence on further melting and metamorphism (Gerdes et al. 2000).

A common characteristic of the granitoid intrusions in all the three study areas (Fichtelgebirge, Oberpfalz, Bavarian Forest) is the evolution from I-type to S-type signatures with time. However, the evolution seems to be diachronous. In the Saxothuringian crust the first pulse (OIC granites and redwitzites in study areas 1 and 2) started at c. $325 \mathrm{Ma}$. Melt generation involved both mantle and crustal inputs and granites were preferentially emplaced into structural discontinuities. The main pulse of the younger S-type granites (YIC in study areas 1 and 2) occurred at 315-290 Ma. The role of the high RHP of granites for the high-temperature metamorphism at c. $320 \mathrm{Ma}$ (Hansen et al. 1989) and the contemporaneous felsic melt generation in the Saxothuringian crust needs to be investigated in further studies.

In the Bavarian Forest, that is a part of the Moldanubian Zone, the magmatic evolution started with dioritic intrusions at c. 334-332 Ma (Fürstenstein Complex) and coeval granodioritic intrusions along the Bavarian Pfahl Shear Zone (palite emplacement at $334 \mathrm{Ma}$, Siebel et al. 2005), i.e. earlier than in the Saxothuringian crust. Interpretation of geochemical characteristics in terms of $\mathrm{S}$ and I-type classification and an assessment of a mantle contribution is not straightforward for the Bavarian Forest granites (Siebel et al. 2008). Most of granitic intrusions are 324-321 Ma old, followed by the last main pulse at $\sim 315 \mathrm{Ma}$ (Siebel et al. 2008). For the anatectic terrain in the Bavarian Forest, Siebel et al. (2012) distinguished two high-grade metamorphic events (345-330 Ma: granulite-facies, 326-323 Ma: amphibolite-facies). The second was coeval with the regional uplift and granite intrusion. The late-orogenic high-temperature metamorphism and the associated magmatism could be triggered by radiogenic heat. Thermal-kinetic modelling by Gerdes et al. (2000) showed that the elevated radiogenic heat in the thickened Moldanubian crust could have caused a substantial temperature increase in the middle and lower crust. On the other hand, the temperature-time path of Kalt et al. (2000) featured a rapid late- to post-orogenic exhumation of the Bavarian Forest that was explained by mantle delamination. Numeric models by Henk et al. (2000) underlined the importance of crustal thickening for the thermal structure of the Variscan crust and also discussed an enhanced heat flow during late-orogenic delamination of parts of the lower lithosphere. However, as has been pointed out by Tropper et al. (2006), it is difficult to critically evaluate and test the various models for explanation of the late-orogenic heating in the Moldanubian crust (mantle delamination versus radiogenic heating) and thus further modelling is needed. 


\section{Conclusions}

Gamma radiation measurements with a portable spectrometer have yielded a large and detailed data set on radioelement concentrations in Variscan granites along the western margin of the Bohemian Massif. For the total of 829 measurements a mean heat production rate of 4.9 $\mu \mathrm{W} / \mathrm{m}^{3}$ was obtained which is far above the global average, estimated between 2.53 and $3.54 \mu \mathrm{W} / \mathrm{m}^{3}$ by different research groups. The granites are identified as moderateto high-heat-producing using the classification scheme implemented for Australian granitic terrains. The high RHP can be explained by crustal reworking and enrichment of heat-producing elements in the Variscan crust.

Most granite intrusions studied here are characterized by $\mathrm{Th} / \mathrm{U}>1$ that can be explained by a combined effect of enriched sources and subsequent differentiation processes. These intrusions occur in Fichtelgebirge (except for the Tin Granite), Bavarian Forest (Hauzenberg and Fürstenstein granites) and among the older granites of the Oberpfalz (Leuchtenberg and Zainhammer, Falkenberg and Liebenstein types). Enrichment in Th could be related to abundance of monazite, as a major carrier of Th in peraluminous granitic rocks.

In contrast, some of the Oberpfalz granites (Flossenbürg, Steinwald, Friedenfels types) are characterized by high $\mathrm{U}$ concentrations and thus $\mathrm{Th} / \mathrm{U}<1$. This in agreement with $\mathrm{U}$ enrichment along the SaxothuringianMoldanubian contact, mobilized from organic-rich sediments as described in previous studies. A clear temporal trend from I- to S-type granites can be found within each of the studied areas. We identified high-heat-producing S-type magmatic bodies, like the Saldenburg granite in the Bavarian Forest, Flossenbürg granite in the Oberpfalz and the G4 granite in the Fichtelgebirge.

Acknowledgements. We are thankful to S. Jandausch for his help during field survey and to C. Dietl for helpful discussions. This project was funded within the scope of "Bodenatlas Bayern" by the State Bavaria, co-financed by the European Union (EFRE-Program Bayern 2014-2020). We gratefully acknowledge the financial support and the permission to publish the data set. We thank D. Hasterok, W. Siebel and an anonymous reviewer for their helpful and constructive comments. We greatly thank handling editor P. Hasalová and journal chief editor V. Janoušek for their valuable comments, advices and corrections which significantly helped to improve the manuscript.

Electronic supplementary material. Supplementary tables of field gamma spectrometry measurements with geographical coordinates are available online at the Journal web site (http://dx.doi.org/10.3190/jgeosci.293).

\section{References}

Adams C, Auld A, Gluyasm J, Hogg SI (2015) Geothermal energy - the global opportunity. Proc Instit Mech Eng, Pt A: J Power Energy 229: 747-754

Artemieva IA, Thybo, Jakobson K, Sorensen NK, NIELSEN LSK (2017) Heat production in granitic rocks: global analysis based on a new data compilations GRANITE2017. Earth Sci Rev 172: 1-26

BEA F (1996) Residence of REE, Y, Th and U in granites and crustal protoliths; implications for the chemistry of crustal melts. J Petrol 37: 521-552

BEA F (2012) The sources of energy for crustal melting and the geochemistry of heat-producing elements. Lithos 153: 278-291

Bea F, Montero P, Zinger T (2003) The nature, origin, and thermal influence of the granite source layer of Central Iberia. J Geol 111: 579-595

Beamish D, Busby J (2016) The Cornubian geothermal province: heat production and flow in SW England: estimates from boreholes and airborne gamma-ray measurements. Geotherm Energy 4: 4, DOI 10.1186/ s40517-016-0046-8

BEARDSMORE G (2004) The influence of basement on surface heat flow in the Cooper Basin. Explor Geophys 35: 223-235

BREITER K (2012) Nearly contemporaneous evolution of the A- and S-type fractionated granites in the Krušné hory/ Erzgebirge Mts., Central Europe. Lithos 151: 105-121

BüLTEMANN HW (1979) Die Uranvorkommen im ostbayerischen Grundgebirge Raum Mähring, Krs. Tirschenreuth/ Opf. Z Dtsch Geol Gesell 130: 575-596

Carl C, Wendt I (1993) Radiometrische Datierung der Fichtelgebirgsgranite. Z geol Wiss 21: 49-72

Casini L, Cuccuru S, Puccini A, Oggiano G, Rossi P (2015) Evolution of the Corsica-Sardinia Batholith and late-orogenic shearing of the Variscides. Tectonophysics 646: 65-78

Chandrasekharam D, Varun C, Garg G, Singh HK, TRUPI G (2014) High heat generating granites of Siwana, Rajasthan. Geoth Res T 38: 625 - 627

Chen F, Siebel W (2004) Zircon and titanite geochronology of the Fürstenstein granite massif, Bavarian Forest, NW Bohemian Massif: pulses of the late Variscan magmatic activity. Eur J Mineral 16: 777-778

Chen F, Siebel W, Satir M (2003) Geochemical and isotopic composition and inherited zircon ages as evidence for lower crustal origin of two Variscan S-type granites in the NW Bohemian Massif. Int J Earth Sci 92: 173-184 De Wall H, Pandit MK, Donhauser I, Schöbel S, Wang W, Sharma KK (2018) Evolution and tectonic setting of the Malani-Nagarparkar Igneous Suite: a Neoproterozoic silicic-dominated large igneous province in NW IndiaSE Pakistan. J Asian Earth Sci 160: 136-158 
de Wall H, SchaArschmidt A, Kämmlein M, Gabriel G, Bestmann M, Scharfenberg L (2019) Subsurface granites in the Franconian Basin as the source of enhanced geothermal gradients: a key study from gravity and thermal modeling of the Bayreuth granite. Int J Earth Sci 108: 1913-1936

Dietl C, Koyi HA, de Wall H, Gössmann M (2006) Centrifuge modelling of plutons intruding shear zones: application to the Fürstenstein Intrusive Complex (Bavarian Forest, Germany). Geodin Acta 19: 165-184

Dill H, WeISER T (1981) Eine Molybdänsulfid-Impsonit Mineralisation aus dem Uranvorkommen Wäldel/Mähring (Oberpfalz). Neu Jb Mineral, Mh: 452-458

DöRr W, Zulauf G (2010) Elevator tectonics and orogenic collapse of a Tibetan-style plateau in the European Variscides: the role of the Bohemian shear zone. Int J Earth Sci 99: 299-325

EBy GN (1992) Chemical subdivision of the A-type granitoids: petrogenetic and tectonic implications. Geology 20: $641-644$

Eby GN, KochHar N (1990) Geochemistry and petrogenesis of the Malani Igneous Suite, northern India. J Geol Soc India 36: 109-130

EDWARDS JW F (1984) Interpretations of seismic and gravity surveys over the eastern part of the Cornubian Platform. In: Hutton DHW, Sanderson DJ (eds) Variscan Tectonics of the North Atlantic Region. Geological Society of London Special Publications 14: 119-124

Faccenda M, Gerya TV, Chakraborty S, (2008) Styles of post-subduction collisional orogeny: influence of convergence velocity, crustal rheology and radiogenic heat production. Lithos 103: 257-287

Fernández M, Marzán I, Correia A, Ramalho E (1998) Heat flow, heat production, and lithospheric thermal regime in the Iberian Peninsula. Tectonophysics 291: 29-53

Finger F, Gerdes A, René M, Riegler G (2009) The Saxo-Danubian Granite Belt: magmatic response to postcollisional delamination of mantle lithosphere below the south-western sector of the Bohemian Massif (Variscan Orogen). Geol Carpath 60: 205-212

FLOYD PA (1972) Geochemistry, origin and tectonic environment of the basic and acidic rocks of Cornubia, England. Proc Geol Assoc 83: 385-404

FÖRSTER A, FöRSTER H-J (2000) Crustal composition and mantle heat flow: implications from surface heat flow and radiogenic heat production in the Variscan Erzgebirge (Germany). J Geophys Res 105/B12: 27.917-27.938

FörSTER H-J (2000) On the origin of the Kösseine granites and their enclaves (Fichtelgebirge, Germany), implications from the composition and age of REE-bearing accessory minerals. Münch Geol H A28: 35-51

Förster H-J, Romer RL (2010) Carboniferous magmatism. In: Linnemann U, Romer RL (eds) Pre-Mesozoic Geology of Saxo-Thuringia - From the Cadomian Active
Margin to the Variscan Orogen. Schweizerbart, Stuttgart, pp 287-308

FÖRSTER H-J, RHEDE D, HeCht L (2008) Chemical composition of radioactive accessory minerals: implications for the evolution, alteration, age and uranium fertility of the Fichtelgebirge granites (NE Bavaria, Germany). Neu Jb Mineral, Abh 185: 161-182

Frattini P, De Vivo B, Lima A, Cicchella D (2006) Elemental and gamma-ray surveys in the volcanic soils of Ischia Island, Italy. Geochem Explor Environ Anal 6: 325-339

GARD M, HaSTEROK D, HAND M, Cox G (2019). Variations in continental heat production from 4 Ga to the present: evidence from geochemical data. Lithos 342-343: 391-406

Gerdes A, Wörner G, Henk A (2000) Post-collisional granite generation and HT-LP metamorphism by radiogenic heating: the Variscan South Bohemian Batholith. J Geol Soc, London 157: 577-587

Gerya T, Perchuk LL, Maresch WV, Willner AP, van REENEN DD, SMit CA (2002) Thermal regime and gravitational instability of multi-layered continental crust: implications for the buoyant exhumation of high-grade metamorphic rocks. Eur J Min 14: 687-699

Gnojek I, Sedlák J, Rapprich V, Skácelová Z, MlČoch B, Krentz O, Casas-García R (2018) Structure of the Carboniferous Altenberg-Teplice Caldera (eastern part of the Krušné hory/Erzgebirge Mts.) revealed by combined airborne and ground gamma-ray spectrometry. J Geosci 63: 3-20

Grasty RL, Holman PB, Blanchard YB (1991) Transportable calibration pads for ground and airborne gammaray spectrometers. Geological Survey of Canada Special Papers 90-23, pp 1-25

HaAck U, Gohn E, Laschtowitz K, Becker KH (1991) Uran, Thorium und Kalium in Gesteinen des Schwarzwaldes und der Oberpfalz. In: EMMERMANN R, LAUTERJUNG J (eds) KTB Report 91-1 - Forschungsergebnisse im Rahmen des DFG-Schwerpunktprogrammes "KTB". Niedersächsisches Landesamt für Bodenforschung, Hannover, pp 269-298

Hansen BT, Teufel S, Ahrendt H (1989) Geochronologie of the Moldanubian-Saxothuringian transition zone, northeast Bavaria. In: EMMERMANN R, WoHLENBERG J (eds) The German Continental Deep Drilling Program (KTB). Springer, Heidelberg, pp 55-65

HaRley TL, WestaWAY R, McCAY AT (2017) Gamma-ray spectrometry in the field: radioactive heat production in the Central Slovakian Volcanic Zone. J Volcanol Geotherm Res 338: 1-24

Hasterok D, Chapman DS (2011) Heat production and geotherms for the continental lithosphere. Earth Planet Sci Lett 307: 59-70

HASTEROK D, GARD M (2016) Utilizing thermal isostasy to estimate sub-lithospheric heat flow and anomalous crustal radioactivity. Earth Planet Sci Lett 450: 197-207 
HASTEROK D, WeBB J (2017) On the radiogenic heat production of igneous rocks. Geosci Front 8: 919-940

Hasterok D, Gard M, WebB J (2018) On the radiogenic heat production of metamorphic, igneous, and sedimentary rocks. Geosci Front 9: 1777-1794

Hecht L, Vigneresse JL, Morteani G (1997) Constraints on the origin of zonation of the granite complexes in the Fichtelgebirge (Germany and Czech Republic): evidence from a gravity and geochemical study. Geol Rundsch 86 (Suppl 1): 93-109

Hecht L, Thuro K, Plinninger R, Cuney M (1999) Mineralogical and geochemical characteristics of hydrothermal alteration and episyenitization in the Königshain granites, northern Bohemian Massif, Germany. Int J Earth Sci 88: 236-252

Henk A, von Blanckenburg F, Finger F, Schaltegger U, Zulauf G (2000) Syn-convergent high-temperature metamorphism and magmatism in the Variscides: a discussion of potential heat sources. In: FrANKE W, HAAK V, Oncken O, TANner D (eds) Orogenic Processes: Quantification and Modelling in the Variscan Belt. Geological Society of London Special Publications 179: 387-399

Huston DL (ed) (2010) An Assessment of the Uranium and Geothermal Potential of North Queensland. Geoscience Australia. Record 2010/14, pp 1-108

Irber W, Förster HJ, Hecht L, Möller P, Morteani G (1997) Experimental, geochemical, mineralogical and O-isotope constraints on the late-magmatic history of the Fichtelgebirge granites (Germany). Geol Rundsch 86 (Suppl 1): S110-124

Jaupart C., Mareschal J-C (2003) Constraints on crustal heat production from heat flow data. In: HoLLAND HD, TUREKIAN KK (eds) Treatise on Geochemistry, Volume 4, The Crust (Rudnick RL ed). Elsevier-Pergamon, Oxford, 65-84

Jaupart C, Mareschal J-C, Iarowsky L (2016) Radiogenic heat production in the continental crust. Lithos 262: 398-427

Kalt A, Berger A, Blümel P (1999) Metamorphic evolution of cordierite-bearing migmatites from the Bayerische Wald (Variscan Belt, Germany). J Petrol 40: 601-627

Kalt A, Corfu F, WiJbrans JR (2000) Time calibration of a $\mathrm{P}-\mathrm{T}$ path from a Variscan high-temperature low-pressure metamorphic complex (Bavarian Forest, Germany) and the detection of inherited monazite. Contrib Mineral Petrol 138: 143-163

Kirkland C, Smithies R, Taylor R, Evans N, McDonald $\mathrm{B}$ (2015) Zircon $\mathrm{Th} / \mathrm{U}$ ratios in magmatic environs. Lithos 212-215: 397-414

Klein T, Kiehm S, Siebel S, Shang CK, Rohrmüller J, Dörr W, Zulauf G (2008) Age and emplacement of late-Variscan granites of the western Bohemian Massif with main focus on the Hauzenberg granitoids (European Variscides, Germany). Lithos 102: 478-507
KLOMÍNsKÝ J, JaRCHOvskÝ T, RAJPOOT G (2010) Atlas of Plutonic Rocks and Orthogneisses in the Bohemian Massif. 1. Introduction. Czech Geological Survey, Prague, pp 1-96

KováŘíková P, Siebel W, JelíneK E, ŠTEMPRoK M, KachlíK V, Holub FV, Blecha V (2007) Petrology, geochemistry and zircon age for redwitzite at Abertamy, NW Bohemian Massif(Czech Republic): tracing the mantle component in Late Variscan intrusions. Chem Erde - Geochem 67: $151-174$

KREŠL M, VAŇKOVÁ V, JANÁČKOVÁ A (1978) Radioactivity and heat production data from several boreholes in the Bohemian Massif. Stud Geophys Geod 22: 165-176

KříbeK B, ŽÁK K, Dobeš P, Leichmann J, Pudilová M, René M, Scharm B, Scharmová M, Hájek A, Holeczy D, Hein UF, Lehmann B (2009) The Rožná uranium deposit (Bohemian Massif, Czech Republic): shear zonehosted, late Variscan and post-Variscan hydrothermal mineralization. Miner Depos 44: 99-128

LEDÉSERT B, HÉBERT RL (2012) The Soultz-sous-Forêts' enhanced geothermal system: a granitic basement used as a heat exchanger to produce electricity. In MiTROVIC K (ed) Heat Exchangers: Basics Design Applications. InTech, London, pp 477-504

Lexa O, Schulmann K, Janoušek V, ŠTíPská P, Guy A, RACEK M (2011) Heat sources and trigger mechanisms of exhumation of HP granulites in Variscan orogenic root. J Metamorph Geol 29: 79-102

LOISELLE MC, Wones DR (1979) Characteristics and origin of anorogenic granites. Geological Society of America, Abstracts with Programs 11: No 7, 468

Lüschen E, Görne S, von Hartmann H, Thomas R, ScHulz R (2015) 3D seismic survey for geothermal exploration in crystalline rocks in Saxony, Germany. Geophys Prospect 63: 975-989

Mareschal JC, JAUPART J (2013) Radiogenic heat production, thermal regime and evolution of continental crust. Tectonophysics 609: 524-534

McCay A, Harley T, Younger P, Sanderson D, CressWELL A (2014) Gamma-ray spectrometry in geothermal exploration: state of the art techniques. Energies 7: 4757-4780

Mclaren S, Sandiford M, Hand M, Neumann N, WYBORN L, BASTRAKOVA I (2003) The hot southern continent, heat flow and heat production in Australian Proterozoic terranes. In: Hillis RR, Muller D (eds) Evolution and Dynamics of the Australian Plate. Geological Society of Australia Special Publications 22: 151-161

McLaren S, Sandiford M, Powell R (2005) Contrasting styles of Proterozoic crustal evolution: a hot-plate tectonic model for Australian terranes. Geology 33: 673-676

McLennan SM, TAYLOR SR (1996) Heat flow and the chemical composition of continental crust. J Geol 104: 369-377 
Meixner AJ, Kirkby AL, Horspool N (2014) Using constrained gravity inversions to identify high-heatproducing granites beneath thick sedimentary cover in the Cooper Basin region of central Australia. Geothermics 51: 483-495

Miller CF, Mittlefehldt DW (1982) Depletion of light rare-earth elements in felsic magmas. Geology 10: $129-133$

Neumann N, Sandiford M, Foden J (2000) Regional geochemistry and continental heat flow: implications for the origin of the South Australian heat flow anomaly. Earth Planet Sci Lett 183: 107-120

O'Brien PJ, Duyster J, Grauert B, Schreyer W, StÖChert B, WeBER K (1997) Crustal evolution of the KTB drill site: from oldest relics to the Late Hercynian granites. J Geophys Res 102: 18203-18220

Puccini A, Xhixha G, Cuccuru S, Oggiano G, Xhixha MK, Mantovani F, Alvarez CR, Casini L (2014) Radiological characterization of granitoid outcrops and dimension stones of the Variscan Corsica-Sardinia Batholith. Environ Earth Sci 71: 393-405

Radiation Solutions (2007) RS-125 Assay Analysis Comments, Reprecision - preliminary. Unpublished RSI Technical Note 2007-1251, pp 1-2

RADIATION SOLUTIONS (2008) CALIBRATION of the RS125/RS-230 Spectrometers. Unpublished RSI Technical Note RSG-102, pp 1-2

Radiation Solutions (2009) Spectrum Stabilization and Calibration for the RSI RS-125 and RS-230 Handheld Spectrometers. Unpublished RSI Technical Note RSG 703, pp 1-6

Richter P, StetTNer G (1979) Geochemische und petrographische Untersuchungen der Fichtelgebirgsgranite. Geol Bavarica 78: pp 1-144

Romer RL, Cuney M (2018) Phanerozoic uranium mineralization in Variscan Europe - more than $400 \mathrm{Ma}$ of tectonic, supergene, and climate-controlled uranium redistribution. Ore Geol Rev 102: 474-504

Röttger B, Fluche B, Voss W, Rehli HJ (1991) Aerogeophysikalische Hubschrauber-Messungen im Umfeld der Kontinentalen Tiefbohrung (KTB) Windisch-Eschenbach (Oberpfalz). Unpublished Technical Report, Bundesanstalt für Geowissenschaften und Rohstoffe, Hannover, pp $1-48$

RUDNICK RR, McDonough FW, O'ConNell RJ (1998) Thermal structure, thickness and composition of continental lithosphere. Chem Geol 145: 395-411

RYBACH L (1988) Determination of heat producing rate. In: Hänel R, Rybach L, Stegena L (eds) Handbook for Terrestrial Heat-Flow Density Determination. Kluwer, Dordrecht, pp 125-141

SANDIFORD M, McLaren S (2002) Tectonic feedback and the ordering of heat producing elements within the continental lithosphere. Earth Planet Sci Lett 204: 133-150
SchaltegGer U (1997) Magma pulses in the Central Variscan Belt: episodic melt generation and emplacement during lithospheric thinning. Terra Nova 9: 242-245

Scharfenberg L, De Wall H (2016) Natürliche Gammastrahlung von Graniten in der Oberpfalz (NordostBayern) - Vergleich von aerogeophysikalischen und in situ-gammasprectroskopischen Messungen. Geol Bl Nordost-Bayern 66: 205-227

Scharfenberg L, De Wall H, Schöbel S, Minor A, MauRER M, PANDit M.K, Sharma KK (2015) In situ gamma radiation measurements in the Neoproterozoic rocks of Sirohi region, NW India. J Earth Syst Sci 124: 1223-1234

Scharfenberg L, De Wall H, BaUer W (2016) In situ gamma radiation measurements on Variscan granites and inferred radiogenic heat production, Fichtelgebirge, Germany. Z Dtsch Ges Geowiss 167: 19-32

Scharfenberg L, Jandausch S, Anetzberger L, Regelous A, Sharma KK, De Wall H (2019) Differences in natural gamma radiation characteristics of Erinpura and Malani granite in NW India. J Earth Syst Sci 128: 137, DOI 10.1007/s12040-019-1166-x

Scheuvens D, Zulauf G (2000) Exhumation, strain localization, and emplacement of granitoids along the western part of the Central Bohemian shear zone (Bohemian Massif). Int J Earth Sci 89: 617-630

Schulmann K, Konopásek J, Janoušek V, Lexa O, LARDEAUX JM, EdEL JB, ŠTíPSKÁ P, UlRich S (2009) An Andean type Palaeozoic convergence in the Bohemian Massif. C R Geosci 341: 266-286

Siebel W, Chen F (2010) Zircon Hf isotope perspective on the origin of granitic rocks from eastern Bavaria, SW Bohemian Massif. Int J Earth Sci 99: 993-1005

Siebel W, Trzebski R, Stettner G, Hecht L, Casten U, HöHNDORF A, MüLLER P (1997) Granitoid magmatism of the NW Bohemian Massif revealed: gravity data, composition, age relations and phase concept. Geol Rundsch 86: 45-63

Siebel W, Chen F, Satir M (2003) Late-Variscan magmatism revisited: new implications from $\mathrm{Pb}$-evaporation zircon ages on the emplacement of redwitzites and granites in NE Bavaria. Int J Earth Sci (Geol Rundsch) 92: 36-53

Siebel W, Blaha U, Chen F, Rohrmüller J (2005) Geochronology and geochemistry of a dyke-host rock association and implications for the formation of the Bavarian Pfahl shear zone, Bohemian Massif. Int J Earth Sci 94: 8-23

Siebel W, Shang CK, Reitter E, Rohrmüller J, Breiter K (2008) Two distinctive granite suites in the SW Bohemian Massif and their record of emplacement: constraints from geochemistry and zircon ${ }^{207} \mathrm{~Pb} /{ }^{206} \mathrm{~Pb}$ chronology, J Petrol 49: 1853-1872

Siebel W, Shang CK, Thern E, Daniš́́K M, RohrmüLler J (2012) Zircon response to high-grade metamorphism as revealed by $\mathrm{U}-\mathrm{Pb}$ and cathodoluminescence studies. Int J Earth Sci 101: 2105-2123 
Siégel C, Bryan S, Purdy D, Gust D, Allen C, Uysal T, ChAmpion D (2012) A new database compilation of whole-rock chemical and geochronological data of igneous rocks in Queensland: a new resource for HDR geothermal resource exploration. Proceedings of the 2011 Australian Geothermal Energy Conference, Melbourne. Geoscience Australia: 239-244

Singh LS, Vallinayagam G (2012) High heat producing volcano-plutonic rocks of the Siner area, Malani Igneous Suite, Western Rajasthan, India. Int J Geosci 3: $1137-1141$

Stettner G (1979) Der Grenzbereich SaxothuringikumMoldanubische Region im Raum Tirschenreuth-Mähring (Oberpfalz) und die Situation des Uran-führenden Präkambriums. Z Dtsch geoln Gesell 130: 561-574

ŠIMÍČEK D, BÁBEK O, LEICHMANN J (2012) Outcrop gammaray logging of siliciclastic turbidites: separating the detrital provenance signal from facies in the foreland-basin turbidites of the Moravo-Silesian Basin, Czech Republic. Sediment Geol 261-262: 50-64

TASÁRYOVÁ Z, JANOUŠEK V, FRÝDA J (2018) Failed Silurian continental rifting at the NW margin of Gondwana: evidence from basaltic volcanism of the Prague Basin (Teplá-Barrandian Unit, Bohemian Massif). Int J Earth Sci 107: 1231-1266

Thomas R, KLEMM W (1994) Microthermometric study of silicate melt in inclusions in Variscan granites from SE Germany: volatile contents and entrapment conditions. J Petrol 38:1753-1765

TiWARI SK, Biswal TK (2019) Paleostress and magma pressure measurement of granite veins in the Neoproterozoic Ambaji granulite, South Delhi Terrane, Aravalli Delhi Mobile Belt, NW India: implications towards the extension-driven exhumation of the middle-lower crustal rocks. J Earth Syst Sci 128: 150

Tropper P, Deibl I, Finger F, Kaindl R (2006) P-T-t evolution of spinel-cordierite-garnet gneisses from the
Sauwald Zone (southern Bohemian Massif, Upper Austria): is there evidence for two independent late-Variscan low-P/high-T events in the Moldanubian Unit? Int J Earth Sci 95: 1019-1037

Trzebski R; Behr H-J, Conrad W (1997) Subsurface distribution and tectonic setting of the late-Variscan granites in the northwestern Bohemian Massif. Geol Rundsch 86 (Suppl 1): 64-78

Van Wees J-D, Stephenson RA, Ziegler PA, Bayer U, McCann T, Dadlez R, Gaupp R, Narkiewicz M, Nitzer F, Scheck M (2000) On the origin of the Southern Permian Basin, Central Europe. Mar Pet Geol 17: 43-59

ViLÀ M, FernándeZ M, JimÉneZ-Munt I (2010) Radiogenic heat production variability of some common lithological groups and its significance to lithospheric thermal modeling. Tectonophysics 490: 152-164

von SeckendorfF V (2012) Der Magmatismus in und zwischen den spätvariscischen permokarbonen Sedimentbecken in Deutschland. SDGG 61: 743-860

ZÁvada P, Schulmann K, RaceK M, Hasalová P, JeřábeK P, Weinberg RF, ŠTíPsKÁ P, RoberTs A (2018) Role of strain localization and melt flow on exhumation of deeply subducted continental crust. Lithosphere 10: 217-238

Zulauf G, MaIer M, StöCKHert B (1997) Depth of intrusion and thermal modeling of the Falkenberg granite (Oberpfalz, Germany). Geol Rundsch 86 (Suppl 1): 87-92

ŽÁK J, Verner K, JANOUŠEK V, Holub FV, KaChlíK V, Finger F, Hajná J, Tomek F, Vondrovic L, Trubač J (2014) A plate-kinematic model for the assembly of the Bohemian Massif constrained by structural relationships around granitoid plutons. In: SCHULMANN K, MARTÍNEZ Catalán JR, Lardeaux JM, Janoušek V, Oggiano G (eds) The Variscan Orogeny: Extent, Timescale and the Formation of the European Crust. Geological Society of London Special Publications 405: 169-196 